\title{
Information Content of Corporate Social Responsibility
}

\section{Disclosures in Europe: An Institutional Perspective}

\author{
Stéphanie Mittelbach-Hörmanseder* \\ Department of Accounting, Finance \& Statistics \\ Institute for Accounting \& Auditing \\ WU Vienna, Welthandelsplatz 2 \\ 1020 Vienna, Austria \\ Email: stephanie.mittelbach-hoermanseder@wu.ac.at \\ Katrin Hummel \\ Department of Business Administration \\ University of Zurich \\ Affolternstrasse 56 \\ 8050 Zurich, Switzerland \\ E-mail: katrin.hummel@,business.uzh.ch \\ Margarethe Rammerstorfer \\ Department of Accounting, Finance \& Statistics \\ Institute for Finance, Banking and Insurance \\ WU Vienna, Welthandelsplatz 2 \\ 1020 Vienna, Austria \\ Email: margarethe.rammerstorfer@wu.ac.at
}

*corresponding author 


\title{
Information Content of Corporate Social Responsibility Disclosures in Europe: An Institutional Perspective
}

\begin{abstract}
For a sample of STOXX Europe-600 constituents and a reporting period of nine years, we investigate the role of the institutional environment on the value relevance of corporate social responsibility (CSR) disclosures in firms' annual reports. Using textual analysis, we construct topic-specific disclosures measures that examine the prevalence of CSR topics with respect to the EU CSR directive, namely environmental, social and employee matters, human rights, and anti-corruption and bribery. The results reveal the value relevance of CSR disclosures, although the sign depends on the regulatory setting; it is positive before the issuance of the CSR directive and negative after it. Furthermore our results indicate that the incremental value relevance of topic-specific CSR disclosure is affected by the institutional environment, specifically, it is negatively related to country-level CSR awareness as well as employee protection and positively related to both, the legal strength and the level of enforcement. Our results also vary depending by the underlying topics.
\end{abstract}

Keywords: CSR disclosures; value relevance; information environment; textual analysis 


\section{Introduction}

There is no question that corporate social responsibility (CSR) reporting has become more important over the last decades on the company level (Gray, Kouhy, \& Lavers, 1995), but it has also gained increased attention from policy makers, such as the European Union, and the SEC. Aiming to trigger change towards a more sustainable economy, the issuance of directive 2014/95/EU (CSR directive) (European Parliament, 2014) has established an important step towards mandatory CSR reporting. The real effects of this regulation have already been confirmed by recent studies (Fiechter, Hitz, \& Lehmann, 2017; Grewal, Riedl, \& Serafeim, 2017).

Despite these increasing regulatory actions/efforts, the question of whether and how CSR disclosures is related to firm value is neither theoretically nor empirically clear. On the one hand, voluntary CSR disclosures is expected to be positively related to firm value because of an information effect through reduced information asymmetry and a stewardship effect through increased monitoring by shareholders (Core, Hail, \& Verdi, 2015; Healy and Palepu, 2001; Leuz and Verrecchia, 2000; Leuz and Wysocki, 2016). However, the direct effect depends on the value-relevance of CSR activities per se. In that respect, CSR activities might be positively related to firm value as postulated by the "business case of sustainability". On the other hand, CSR activities might cater to stakeholders at the expense of shareholders, and thereby generate a detrimental effect on firm value. Not surprisingly, empirical evidence on the relationship between CSR disclosures and firm valuation is mixed with some studies 
revealing a positive relationship (e.g. Cahan, De Villiers, Jeter, Naiker, \& Van Staden, 2016; Dhaliwal, Li, Tsang, \& Yang, 2014; Ioannou and Serafeim, 2014), and other studies revealing a negative relationship (e.g. Richardson and Welker, 2001; Ullmann, 1985; Vance, 1975). One potential reason for these mixed findings might be the variety of different measures of CSR disclosures that prior studies apply. These measures range from the mere issuance of stand-alone CSR reports (Dhaliwal, Li, Tsang, \& Yang, 2011; Dhaliwal et al., 2014; Dhaliwal, Radhakrishnan, Tsang, \& Yang, 2012) to measures that relate to the quality and/or quantity of CSR disclosures based on content analyses and hand-collected data (Clarkson, Fang, Li, \& Richardson, 2013; Lu, Shailer, \& Yu, 2016; Plumlee, Brown, Hayes, \& Marshall, 2015; Richardson and Welker, 2001) or proprietary data (e.g. Cahan et al., 2016; Gao, Dong, $\mathrm{Ni}, \& \mathrm{Fu}, 2015)$.

Another potential reason for the inconsistent findings relates to the institutional environment in the context of CSR disclosures. Evidence suggests that the institutional environment plays an important role in the value-relevance of disclosures (e.g.,Hail and Leuz, 2006; Hope, 2003; Leuz, Nanda, \& Wysocki, 2003). Specifically, the "incentive-based" view on reporting posits that the institutional environment provides certain incentives for firm disclosures that need to be considered when studying the value-relevance of disclosures. This conception is also confirmed by the few empirical studies that investigate the role of the institutional environment in the value relevance of CSR disclosure. However, the direction of this relationship is currently unclear which primarily stems from differences in the measure of the institutional environment. For instance, Cahan et al. (2016) aggregate variables that proxy for the legal environment as well as CSR awareness into a single factor. The authors find a negative relationship with firm value, thereby indicating that CSR disclosures is less value relevant in countries with a stronger institutional environment. However, due to the broadness of the measure, the different effects cannot be disentangled. Contrary to Cahan et al. (2016), 
Dhaliwal et al. (2014); Dhaliwal et al. (2012) find a value-increasing effect of a strong CSR environment.

Against the background of these mixed findings, this study aims to investigate how the institutional environment shapes the inclusion of CSR topics in annual reports. We therefore follow a two-step approach. First, we analyze the value-relevance of topic-specific CSR disclosures based on a nested Ohlson (1995) model, investigating the influence of CSR disclosures on share price. In addition, we control for the issuance of the CSR directive in this model. Contrary to the majority of the existing studies, we construct topic-specific CSR disclosures measures based on a methodology recently introduced by Hoberg and Maksimovic (2015) and Hummel, Mittelbach-Hoermanseder, Cho, \& Matten (2017). Therefore, we rely on topics requested by the CSR directive, namely, environmental matters, social matters, employee matters, human rights, corruption and bribery. For each CSR topic, we search the annual reports for a search term and extract twenty-word-windows around every search term to automatically derive valid topic vocabularies, resulting in six distinct topic vocabularies. By focusing on specific CSR disclosures topics, we are able to enlighten the prior mixed empirical evidence, which is especially scarce for investigating separate topics (except for Bernardi and Stark (2018); Ioannou and Serafeim (2017) in the context of firm valuation and recently Cannon, Ling, Wang, \& Watanabe (2017) for firm's competitive advantages).

Second, we examine how the institutional environment relates to the value-relevance of CSR disclosures. Based on prior studies (Cahan et al., 2016; De Villiers and Marques, 2016; Ernstberger, Krotter, \& Stadler, 2008; Isidro and Marques, 2015; Leuz et al., 2003; Wang and $\mathrm{Yu}, 2015)$, we focus on four different institutional factors, CSR awareness, employee 
protection, legal environment and enforcement, thereby extending the prior studies' evidence on the role of the institutional environment in general.

For a sample of firms listed on the STOXX Europe 600 index in the reporting period 20082016 our results reveal that all the topic-specific CSR disclosures are value-relevant; however, the coefficients vary depending on the regulatory setting. Specifically, all the topics reveal a negative and significant relationship for the year 2014, when the CSR directive was issued, and later. For the period before, where the characteristics of a purely voluntary setting apply and companies can differentiate themselves from others through their voluntary disclosure, we find a positive relationship, significant for social matters, human rights and corruption. Our bivariate findings also provide evidence that the disclosure of the topics is often accompanied by the disclosure of the other considered topics in annual reports.

In line with previous literature we also account for the issuance of a separate CSR report; however, the issuance of a standalone CSR report is not significant and our results remain unchanged. Thus, the considerations of the mere publication of a CSR report provides only limited insights. Also, we include textual characteristics, such as readability and tone; both of the measures do not exhibit any significance, indicating the importance of our approach to using topic-specific measures.

The results from the second step provide evidence that the incremental value-relevance of the CSR topics is indeed shaped by the institutional environment and that our four factors grasp different country-level institutional aspects. We find that the CSR awareness of a country has a negative and significant relationship with all topic-specific CSR disclosures, revealing that the importance of CSR disclosures is limited if a country already exhibits a certain level of CSR awareness. The same finding applies to our factor measuring employee protection. The result is consistent with Matten and Moon (2008) implicit-explicit framework. Specifically, in 
countries with higher CSR awareness and stronger employee protections, CSR disclosures become more implicit and thus less value relevant. Both the legal environment and the level of enforcement exhibit a positive relationship for some of the topics. It is significant for human rights, corruption and bribery for the factor measuring the strength of the legal environment and all the topics, except for corruption and bribery, for the level of enforcement. This finding is in line with Dhaliwal et al. (2014); (2012). Thus, in countries with stronger legal environments and enforcement, the reliability of the disclosed information is higher. However, it varies depending on the topic. For the topics with lower similarity scores, the legal strength is significant, and for those with higher scores it is the level of enforcement.

Bearing in mind that prior literature suggests a relationship between CSR performance and disclosures (Al-Tuwaijri, Christensen, \& Hughes, 2004; Hummel and Schlick, 2016), we also control for CSR performance; our results indicate that an inclusion in the Dow Jones Sustainability Index (DJSI) has a positive effect on the incremental value relevance of CSR disclosure whereas the continuous asset 4 score is not significant. We do not find any evidence that this relationship differs depending on the CSR performance of the respective company.

This paper contributes to the literature in various ways. First, with respect to the institutional environment, the recent literature has mainly concentrated on one or two (partially manually) aggregated factors (Cahan et al., 2016; Dhaliwal et al., 2014; Dhaliwal et al., 2012). In contrast, we perform a principal component analysis of all our variables and develop four distinct factors measuring different institutional characteristics on the country level. Our results show that the distinct factors are variously related to the incremental value relevance of CSR disclosures. Thus, we are able to disentangle the theoretical reasoning of the role of the institutional environment on the value relevance into CSR awareness and employee 
protection that is attributable to an information effect as well as legal strength and enforcement resulting from a stewardship effect.

Second, to the best of our knowledge, our paper is among the first to investigate the value relevance of topic-specific CSR disclosures. Except for the studies provided by Ioannou and Serafeim (2017) and Bernardi and Stark (2018), there are currently no studies that simultaneously investigate the value relevance of different CSR disclosures topics. Prior studies are often restricted to environmental, social or overall sustainability disclosures, but do not provide insights into the value relevance of different CSR topics. This is even more surprising considering Plumlee et al. (2015) find that, when splitting their disclosures measure into nature and type, their results become more precise. Within our nested regression models, we do not only consider whether specific topics were addressed, but also account for how they were addressed. We do so by comparing every annual report to our automatically generated topic-specific vocabularies and come up with similarity scores, measuring how close the annual report is to the respective topic vocabulary. Moreover, none of the existing value relevance studies focus on the disclosures of CSR information in firms' annual reports, although annual reports are the major disclosures channel for firms to communicate with capital market participants (Amernic, 1992; Anderson and Epstein, 1995; O’Donovan, 2002; Salancik and Meindl, 1984). Since we derive our topics from the CSR directive, which is not industry specific but has a broad circle of users, our results also have the advantage of generalizability and thus, are easily transferable.

Third, the use of textual analysis enables us to overcome some of the weaknesses of prior studies, particularly the use of aggregated (often proprietary) CSR disclosures scores in large sample settings or small sample sizes in case of manual content analyses. Because the analyses are derived by computational textual analysis, they are, in large part, independent of 
any judgment and easily replicable to apply those measures to other samples and provide comparable research. To make use of the advantages of textual analysis and allow for further comparative research, we also contribute to future research by providing our word lists with respect to the six topics mandated by the CSR directive.

Fourth, there is also concern that CSR disclosures are highly time-driven, and thus, one-year studies such as Cahan et al. (2016) only provide limited evidence. Because we perform a longitudinal study over a horizon of nine years together with topic-specific CSR disclosures we are able to provide more robust evidence. Specifically, our results reveal that the inclusion of time-fixed effects is important.

Finally we are also among the first studies to respond to the call by Leuz and Wysocki (2016) to investigate the value relevance of nontraditional disclosures.

Therefore, our contribution is manifold. Additionally, we further provide evidence to practitioners (especially preparers) to understand, how topic-specific CSR disclosures affect capital markets. Specifically we show that CSR disclosures are negatively related to price after the issuance of the CSR directive and the impact on the explanatory power of supplementary CSR disclosures by topic is negatively related to a country's CSR awareness and employee protection. Thus, in such settings preparers would need to put less emphasis on explicit reporting. However the legal strength and enforcement generally increase the explanatory power. Additionally, with respect to further advances in mandatory CSR reporting for small- and medium-sized companies, we provide evidence for standard setters that, despite uniform standards, the processing of the information content of topic-specific disclosures by capital markets may be driven by different aspects of the institutional environment and thus should be considered. 
This paper is structured as follows. First, we present the institutional background relating to the CSR directive and a review of the literature, followed by the theoretical background and the development of the hypotheses. Next, the research design is described, particularly the empirical model, the sampling, the topic-specific disclosures measures and the measurement of the institutional environment. The descriptive and multivariate findings as well as insights from additional robustness tests are then presented. The final section draws together the main findings and concludes.

\section{Institutional Background and Prior Literature}

\subsection{CSR Directive}

It was only in April 2014 that the European Union passed a directive mandating the "disclosures of non-financial and diversity information" for large companies from 2017 onwards (2014/95/EU). The directive specifically aims at firms listed on EU exchanges or with significant operations within the EU, which are defined as large or public-interest entities (PIEs) by EU member states due to their activities, size or number of employees ${ }^{1}$. Article one of the CSR directive states that companies shall report, either in the management report a nonfinancial statement or a separate nonfinancial report, thematic aspects relating, at a minimum, environmental, social and employee matters, respect for human rights, anticorruption and bribery matters.

\footnotetext{
${ }^{1}$ The disclosures requirements for non-financial information apply to certain large companies with more than 500 employees, as the cost of obliging small and medium-sized enterprises to apply them could outweigh the benefits.
} 
This nonfinancial information should lead to more robust growth and employment and increased trust among stakeholders, including investors and consumers ${ }^{2}$. However, the directive neither requires the application of one single standardized CSR framework nor assurance by an auditor. The directive only specifies that firms may prepare their CSR disclosures based on high quality, broadly recognized national, EU-based or international frameworks and that an auditor should check that the nonfinancial information was provided. Thus, the directive has been criticized because the guidelines are still not specific enough and provide companies too much room for flexibility. At the same time, the publication of the directive has also been seen as an important milestone towards signaling the importance of sustainability for the EU.

Regardless of its criticism, the recent literature shows that the publication of the CSR directive has already been economically significant. Specifically, Grewal et al. (2017) finds that the announcement of the directive has led to a negative market reaction, confirming the importance of its implications for equity investors. The authors also show that the reaction depends on environmental, social, and governance (ESG) score; disclosures is more (less) pronounced for weak (strong) ESG-performing firms. Furthermore, Fiechter et al. (2017) show that the issuance of the CSR directive has led to increased CSR activities among affected firms that did not report prior to the directive.

\subsection{Prior Literature}

We organize the literature investigating the information content of CSR disclosures in two streams. In the first strand, we discuss studies that focus on the value relevance of CSR disclosures. The second strand relates to studies that address the value relevance of CSR disclosures in the context of the institutional environment.

\footnotetext{
${ }^{2}$ Communication from the commission, guidelines on non-financial reporting (methodology for reporting nonfinancial information) 2017/C 215/01, European Commission (2017).
} 
Among the first studies on the value-relevance of CSR disclosures are the studies provided by Dhaliwal et al. (2011) and Dhaliwal et al. (2012). Using a US sample, Dhaliwal et al. (2011) show that firms with higher costs of equity are more likely to release a separate CSR report and that first-time reporters can decrease their cost of equity capital in subsequent years. A subsequent study that focuses on a worldwide sample reveals that the publication of a standalone CSR report is associated with lower earnings forecast errors, i.e., higher analysts' earnings accuracy (Dhaliwal et al., 2012). Other studies focus not only on the issuance of a separate CSR report but also on the quantity or quality of the disclosed CSR information. These studies tend to support the value-enhancing effects of CSR disclosures. For instance, both Clarkson et al. (2013) and Plumlee et al. (2015) focus on environmental disclosures and reveal negative associations with firms' cost of equity capital (Clarkson et al., 2013) and positive associations with expected future cash flows (Plumlee et al., 2015). Similarly, Gao et al. (2015) find that high-quality CSR disclosures have greater analyst coverage, a higher level of institutional ownership and greater stock liquidity, with all of these resulting in a higher valuation in equity offerings and a lower cost of debt. Only early evidence from Richardson and Welker (2001) find evidence for a value-decreasing effect of CSR disclosures, specifically social disclosures for a sample of 124 Canadian firms. These studies are complemented by a few studies that focus on CSR disclosures in a mandatory setting (Barth, Cahan, Chen, \& Venter, 2017; Ioannou and Serafeim, 2017). Specifically, Ioannou and Serafeim (2017) focus on mandatory CSR disclosures in four countries and find a positive and significant relationship for the overall Bloomberg ESG disclosures score with firm value, as well as for the environmental, social, and governance disclosures scores separately. Similarly, Barth et al. (2017) examine the relationship between integrated report quality and firm value in South Africa, where integrated reporting is mandatory. Their results reveal positive and significant associations between integrated report quality and firm value, via both a capital market channel and a real effects channel. 
The second stream of studies specifically examines the role of the institutional environment in the context of financial and CSR disclosures. While there is extensive research with regard to financial disclosures (Burgstahler, Hail, \& Leuz, 2006; Core et al., 2015; Francis, Nanda, \& Olsson, 2008; Gaio, 2010; Hail and Leuz, 2006; Isidro and Marques, 2015; Leuz et al., 2003; Wang and $\mathrm{Yu}, 2015)$, in the context of CSR disclosures, this research is still in its beginning and comprises only a limited number of studies (Cahan et al., 2016; De Villiers and Marques, 2016; Dhaliwal et al., 2014; Dhaliwal et al., 2012; Simnett, Vanstraelen, \& Chua, 2009). With respect to CSR disclosures per se, the empirical evidence suggests that firms that are domiciled in stakeholder-oriented countries provide higher levels of CSR disclosures (Kolk and Perego, 2010; Simnett et al., 2009; Van der Laan Smith, Adhikari, \& Tondkar, 2005). With respect to the value relevance of CSR disclosures, Dhaliwal et al. (2012) investigate under which institutional setting CSR disclosures improves analyst forecast accuracy. For 7,108 firm-year observations from 1994 to 2007, their finding that the publication of a standalone CSR report is associated with lower earnings forecast errors is even more pronounced for countries that are more stakeholder-oriented and for companies with greater opacity in their financial disclosures. Considering the same cross-country setting, Dhaliwal et al. (2014), find the same phenomenon for cost of capital. The negative association between the issuance of a stand-alone CSR report and the cost of equity capital is also more pronounced for stakeholder-oriented countries. Thus, their results indicate that the relevance of the same type of disclosures for investors depends on the business culture and the institutional environment.

More recently, in a cross-country setting including 21 countries, Cahan et al. (2016) examine the relationship between overall CSR disclosures and firm value for 676 firms for 2008 . Based on a proprietary CSR disclosures proxy provided by KPMG they confirm a positive association between firm value, as measured by Tobin's Q, and CSR disclosures only for the unexpected and not the expected part of the disclosures. Furthermore, the authors' results 
reveal that the expected CSR disclosures is significantly positively associated with the strength of the country-level institutions. Specifically, they show that under transparent conditions, unexpected CSR disclosures tend to be less incrementally informative than those in countries with weak institutions. Note that this finding is contrary to Dhaliwal et al. (2014); (2012). Similarly, for using a cross-country value relevance study, De Villiers and Marques (2016) confirm a positive relationship between the CSR disclosures level/quality and the strength of the institutional environment. Specifically the authors examine a sample of 366 European firms across four years based on the Global Reporting Initiative (GRI) reporting level and find a positive and significant association between CSR disclosures and share price. De Villiers and Marques (2016) show that this relationship is more pronounced in countries with stronger governance mechanisms - which is a finding that is contrary to the finding obtained by Cahan et al. (2016).

Taken together, the results tend to show that CSR disclosures provides additional information to the market. In addition, there is some empirical evidence revealing that the value relevance of CSR disclosures depend on the strength of the institutional environment (Cahan et al., 2016; De Villiers and Marques, 2016; Dhaliwal et al., 2014; Dhaliwal et al., 2012). However, the empirical evidence regarding the direction of the effect of the institutional environment is still mixed.

\section{Empirical Predictions and Hypotheses}

\subsection{Value Relevance of CSR Disclosures}

Economic theory predicts that increased voluntary disclosures has a positive impact on firm value through two channels: i) an information effect that reduces information asymmetry, increases awareness of the firm's existence and enlarges the investor base or increased liquidity (Healy and Palepu, 2001), which is largely confirmed for financial disclosures (Leuz 
and Verrecchia, 2000; Leuz and Wysocki, 2016), and ii) a stewardship effect because of increased monitoring of the manager by the shareholders. In the context of CSR disclosures, the information effect is ex ante not that clear, which primarily stems from opposing views on the value relevance of CSR activities per se. ${ }^{3}$ These opposing theoretical predictions regarding the relationship between CSR disclosures and firm valuation are also reflected in prior studies' mixed empirical evidence.

On the one hand, CSR activities might be positively related to firm value due to competitive advantages (Cannon et al., 2017); increased sales volumes - particularly among high-quality customers (Lev, Petrovits, \& Radhakrishnan, 2010); better reputation (Fombrun and Shanley, 1990); and higher innovation and operational efficiency (Dixon-Fowler, Slater, Johnson, Ellstrand, \& Romi, 2013). This line of reasoning is often referred to as the "business case of sustainability". On the other hand, the view exists that CSR activities cater to stakeholders at the expense of shareholders and thereby generate a detrimental effect on value by affecting a firm's operations, for example reforming costs or production cost (Pagano and Volpin, 2005). A negative effect of costly CSR activities on financial performance is also confirmed by early evidence, e.g. Ullmann (1985); Vance (1975) or Peng and Yang (2014). Richardson and Welker (2001) find clear negative effects of costly CSR activities on financial performance,

Against the background of these differences in the theoretical reasoning for CSR disclosures and the inconsistent empirical evidence, we assert that CSR disclosures convey information beyond that provided by financial disclosures, regardless of the aggregate valuation implication of CSR activities. However, in contrast to prior studies, we neither focus on the issuance of a separate CSR report nor an overall CSR disclosures level, but instead examine the disclosures of topic-specific CSR information in firms' annual reports, as requested by the CSR directive. We concentrate on the annual report since it is the main public document

\footnotetext{
${ }^{3}$ Note that also in the financial disclosures literature the relationship is not without controversy. For instance, Johnstone (2014) shows a value-decreasing effect of higher information precision.
} 
presented by companies and, thus, has a significant influence on the way capital markets perceive information and react to the release of that information via a change in the share price (Amernic, 1992; Anderson and Epstein, 1995; O’Donovan, 2002; Salancik and Meindl, 1984). Consistent with Plumlee et al. (2015), we assert that more granular CSR disclosure information should provide better evidence. Therefore, we are particularly interested in the information content of different topics of CSR information in firms' annual reports. We are also convinced that this approach allows us to better grasp the CSR activities within the disclosures score. Specifically, we focus on those topics for which disclosures is requested by the CSR directive, namely, environmental matters, social and employee matters, respect for human rights, and anti-corruption and bribery matters. We formally posit the following hypotheses:

\section{H1: Annual report disclosures on}

a) environmental matters,

b) social and employee matters,

c) human rights matters, and

d) anti-corruption and bribery matters

provide informational content to capital market participants that is in addition to financial information.

The approach considering different topics at once is new, to our knowledge. Prior research typically focuses on aggregated measures of CSR disclosures, such as the issuance of a standalone CSR report $(2011,2014 ; 2012)$ or an overall CSR disclosures score (Barth et al., 2017; Cahan et al., 2016; Gao et al., 2015; Ioannou and Serafeim, 2017). A few studies focus on only environmental disclosures (Clarkson et al., 2013; Cormier, Magnan, \& van Velthoven, 2005; Plumlee et al., 2015) or social disclosures (Richardson and Welker, 2001), showing that companies report differently based on the considered topic. With respect to environmental 
matters, the literature shows that the impact of disclosures is often industry specific (Blacconiere and Patten, 1994; Cho, Roberts, \& Patten, 2010; Matsumura, Prakash, \& VeraMuñoz, 2014). With respect to firm value, empirical evidence tends to reveal a positive association (Clarkson et al., 2013; Cormier, Ledoux, \& Magnan, 2011; Plumlee et al., 2015). For social and employee matters, the only study that focuses exclusively on social disclosures reveals a negative effect on firm value (Richardson and Welker, 2001). With respect to disclosures on human rights as well as corruption and bribery, these topics are not covered by prior studies.

Recently, Ioannou and Serafeim (2017) and Bernardi and Stark (2018) separately investigated the three components of the Bloomberg ESG score. The former provide evidence for the value relevance of the three components; the latter investigate the relationship with accuracy of analyst forecasts and find that the relationship is particularly pronounced for environmental disclosures. The topic-specific approach we propose goes one step further by considering separate topics based on the CSR directive and by applying textual analysis. We expect to add new evidence to the literature, because as also Hummel et al. (2017); Matten and Moon (2008) show companies report differently with respect to topics depending on the institutional environment.

\subsection{The Role of the Institutional Environment}

There is extensive research showing that firm disclosures and potential economic consequences vary considerably depending on the institutional environment (Hail and Leuz, 2006; Hope, 2003; Leuz et al., 2003; Wang and Yu, 2015). Specifically, the literature shows that institutional factors substantially shape firm's reporting incentives (Ball, Kothari, \& Robin, 2000; Ball, Robin, \& Wu, 2003; Burgstahler et al., 2006; Bushman and Piotroski, 2006; Daske, Hail, Leuz, \& Verdi, 2008, 2013; Leuz et al., 2003). Based on the prior 
literature (Cahan et al., 2016; Core et al., 2015; Dhaliwal et al., 2014; Dhaliwal et al., 2012; Wang and $\mathrm{Yu}, 2015$ ), we focus on four institutional factors, namely, CSR awareness, employee protection, legal environment and enforcement.

With respect to the role of CSR awareness and employee protection, the literature shows significant variation in voluntary CSR disclosures in cross-country settings (Chen and Bouvain, 2009; Fifka, 2013b; Kolk and Perego, 2010; Maignan and Ralston, 2002; Orij, 2010; Van der Laan Smith et al., 2005). Specifically, the evidence attributes an important influence to the institutional environment since it shapes the social and political process defining stakeholders' interests (Aguilera and Jackson, 2003; Ioannou and Serafeim, 2012). It is the incentives provided by a certain institutional framework that are crucial to the adoption of certain CSR-friendly behavior and reporting (Campbell and Slack, 2008; Ioannou and Serafeim, 2014). However, theoretical predictions and empirical evidence on the direction of the relationship between CSR-related institutional factors and the value relevance of CSR disclosures are mixed. On the one hand, one may argue that CSR disclosures in countries with strong CSR awareness and employee protection is more credible due to the stronger monitoring of firms' CSR actions and disclosures by their stakeholders. For instance, CSR disclosures on employee matters might result in stricter consequences in countries with stronger employee protection. As a consequence, CSR disclosures is more value-relevant in these countries. Such a positive effect of the public awareness of CSR issues and employee protection is found by Dhaliwal et al. (2014); (2012). They find that the negative relationship between CSR disclosures and forecast error (Dhaliwal et al., 2012) or cost of capital (Dhaliwal et al., 2014) is more pronounced in stakeholder-oriented countries. On the other hand, one may also argue that there is a value-decreasing effect of a strong CSR-related institutional environment. Specifically, based on the national business systems approach (Hall and Soskice, 2001; Maurice and Sorge, 2000; Maurice, Sorge, \& Warner, 1980), Matten and 
Moon (2008) argue that firms located in liberal market economies (LMEs), such as the US, provide more explicit CSR disclosures because LMEs encourage corporate CSR actions due to weak governmental/regulatory CSR actions. Likewise, firms located in coordinated market economies (CMEs), such as most European countries, provide less explicit CSR disclosures because CMEs are characterized by extensive CSR regulations and governmental involvement. Empirical evidence tends to support this framework (Chen and Bouvain, 2009; Fifka, 2013a; Hummel et al., 2017; Maignan and Ralston, 2002). As a consequence, stronger regulatory CSR actions might decrease the value relevance of CSR disclosures since CSR disclosures and CSR actions are more implicit. Thus, CSR disclosures do not provide a means for companies to differentiate themselves from other firms since all companies are subject to the same regulations with respect to for instance employee protection. Such a negative relationship is found by Cahan et al. (2016); however, it should be noted that Cahan et al. (2016) focus on an aggregate measure of institutional strength. As a consequence, we do not know which of our four institutional factors drive this effect. Based on these mixed theoretical predictions and empirical evidence, we posit a nondirectional hypothesis for the effect of CSR awareness and employee protection on the value relevance of CSR disclosures and formally posit the following:

\section{H2: The level of}

a) CSR awareness and

b) employee protection

of the respective country is related to the incremental value relevance of CSR disclosures.

With respect to the legal environment and enforcement, theoretical and empirical evidence is also mixed. On the one hand, one might argue that the stewardship role of disclosures becomes less important in countries with a strong legal environment since such an 
institutional environment itself can establish/guarantee alignment between shareholders and managers. In this case, disclosures and the legal environment act as substitutes. Empirical evidence for such a negative relationship is provided by Core et al. (2015), (2016) and Dhaliwal et al. (2012). On the other hand, one might argue that strong legal environments and enforcement provide stronger reporting incentives. Specifically, stronger legal systems have a negative effect / impede earnings management (Burgstahler et al., 2006; Jeanjean and Stolowy, 2008; Leuz et al., 2003) and foster the quality and effectiveness of accounting standards (Ball et al., 2000; Ball et al., 2003; Wang and Yu, 2015). Thus, in strong legal environments, the reliability of the disclosed information is higher, which translates into higher firm valuations. This relationship is particularly true for voluntary disclosures since a strong legal environment reduces the discretion for opportunistic disclosures (legitimacy reasons). In this case, firms provide information if the marginal benefits of disclosures are equal to or higher than the marginal costs (Verrecchia, 1983). Empirical evidence for such a positive impact of the legal environment and enforcement on the value-relevance of disclosures is provided by Wang and Yu (2015). Again, we do not hypothesize on the direction of the relationship between the institutional environment and the value relevance of CSR disclosures. We therefore posit the following hypotheses:

\author{
H2: The level of \\ c) the legal environment and \\ d) enforcement \\ of the respective country is related to the incremental value relevance of CSR \\ disclosures.
}




\section{Research Design and Variables}

\subsection{Empirical Model}

To assess how the institutional environment shapes the incremental value relevance of topicspecific CSR disclosures in annual reports, we use a two-step procedure. First, we select the relevant CSR topics, by investigating which topics provide significant informational content to the capital market. Therefore, we analyze a traditional value-relevance model based on Ohlson (1995) and investigate whether the disclosures of topic-specific CSR information in the annual report is significant. Specifically, we run the following nested panel regressions with fixed effects for cross-sections and years:

$P=\alpha_{0}+\alpha_{1} B V E+\alpha_{2} E A R N+\varepsilon$

$P=\beta_{0}+\beta_{1} B V E+\beta_{2} E A R N+\beta_{2+i} T_{i}+\beta_{8+i} T_{i} *$ POST $+\varepsilon$

Here, $P$ denotes the share price of a certain company, $B V E$ is the book value per share and $E A R N$ stands for the earnings per share. All the data refer to the fiscal year end. $T_{i}$ proxies the topic-specific CSR information in the annual report, namely, information on the environment $\left(T_{\mathrm{ENV}}\right)$, social matters $\left(\mathrm{T}_{\mathrm{SOC}}\right)$, employee matters $\left(\mathrm{T}_{\mathrm{EMPL}}\right)$, human rights $\left(\mathrm{T}_{\mathrm{HR}}\right)$, corruption ( $\left.\mathrm{T}_{\mathrm{CORR}}\right)$ and bribery $\left(\mathrm{T}_{\mathrm{BRIB}}\right)$. To control for the issuance as well as the presence of the CSR directive, from which we extracted the topics, we include interaction terms of topic-specific CSR disclosures with POST. Here, POST denotes the presence of the CSR directive that was communicated to the market in 2014 and thus amounts to 1 for the years 2014, 2015 and 2016 and zero otherwise. ${ }^{4}$ In doing so, we take into account the recent results concerning the real effects of the CSR directive (Fiechter et al., 2017; Grewal et al., 2017). We provide a list of all our variables in Appendix I.

\footnotetext{
${ }^{4}$ Note that we do not include POST as additional variable because POST is perfectly correlated with the yearfixed effects.
} 
Second, in case the textual variables $T_{i}$ exert a significant impact on prices, we continue to analyze the incremental value relevance of the respective CSR disclosures with respect to the institutional environment. Therefore, we first calculate the change in the explanatory power of the Ohlson (1995) model, incremental to the addition of topic-specific CSR information, given by $R_{\text {incr }}^{2}\left(T_{i}\right)=R^{2}\left(T_{i}\right)-R^{2}(B)$, where $R^{2}(B)$ is the adjusted $R^{2}$ of the baseline model (1) and $R^{2}\left(T_{i}\right)$ is the adjusted $R^{2}$ after adding the topic-specific CSR disclosures $T_{i}$ to the pooled regression model, both at the firm level ${ }^{5}$. The advantage of this comparison is that each (adjusted) $R^{2}$ only considers the explanatory power of the topic-specific CSR disclosures for the dependent variable and enables us to consider the incremental information content on the stock price, $P$, by the CSR disclosures (Barth, Landsman, Lang, \& Williams, 2012). Next, to provide insights into how different institutional environments affect the information processing of how the additional topic-specific CSR disclosures convey new information and, thus, significantly influence the incremental $R_{\text {incr }}^{2}\left(T_{i}\right)$, we run the following regression model with country- and industry-fixed effects:

$R_{\text {incr }}^{2}\left(T_{i}\right)=\mu_{0}+\mu_{i}$ Country_Factor $_{i}+\varepsilon$

where Country_Factor ${ }_{i}$ are the factors resulting from a principal component analysis (PCA) considering the strength of the institutional environment (see 4.4). Further analyses are the subject of our robustness tests.

\subsection{Sampling}

We concentrate on firms listed in the STOXX Europe 600 index as of October, 2016. Our unique dataset is based on the manual collection of the firms' annual reports for the period ranging from 2008 to 2016, resulting in 5,023 annual reports.

\footnotetext{
${ }^{5}$ We consider companies only where observations are available for the whole observation period, namely at least 8 years.
} 
Insert Table 1 about here

Panel A of Table 1 provides an overview of the sample selection process. In total, we obtain 5,023 reports (i.e., firm-year observations) for our sample of 600 firms and 9 reporting years. As it is not possible to process 850 of the reports in the textual analysis for various reasons, our sample is reduced to 4,173 observations. ${ }^{6}$ We drop 212 observations due to missing values for the dependent variables. Our final sample consists of 3,961 observations for equations (1) and (2). For equation (3) the sample is reduced to 3,303 observations because we request at least 8 observations per firm in order to enter the pooled regressions.

Panel B of Table 1 presents the sample distribution by industry group based on Fama and French (2017). Panel C of Table 1 provides the sample distribution by country.

\subsection{Topic-specific CSR Disclosure Measures}

To generate a CSR disclosures measure with respect to different CSR topics, we use textual analysis. Specifically, prior research in financial reporting provides evidence for a positive relationship between the readability of a firm's financial disclosures and market efficiency (Biddle, Hilary, \& Verdi, 2009; Li, 2008; Miller, 2010). In addition, Lehavy, Li, \& Merkley (2011) show that readability is negatively correlated with analyst following. Thus, CSR disclosures measured through textual components convey new information beyond that included in financial disclosures. To overcome the main caveats of CSR disclosures research, in particular small sample sizes, limited replicability and intercoder reliability in the case of manual disclosures assessments, and limited transparency in the case of proprietary data, we

\footnotetext{
${ }^{6}$ Files that cannot be processed in the textual analysis are typically PDF files with copy protection.
} 
apply computer-assisted textual analysis and calculate topic-specific CSR disclosures measures.

Specifically, we expect CSR disclosures measured through textual components to convey new information beyond that included in financial disclosures. Recently, the use of textual analysis to assess CSR disclosures has arisen (e.g. Cannon et al., 2017; Loughran, McDonald, \& Yun, 2009; Melloni, Caglio, \& Perego, 2017). Those studies often refer to textual characteristics, such as readability, tone, optimism or certainty and text length (Cho et al., 2010; Melloni et al., 2017; Muslu, Mutlu, Radhakrishnan, \& Tsang, 2016; Nazari, Hrazdil, \& Mahmoudian, 2017). Few studies assess CSR disclosures with respect to specific topics. For instance, Loughran et al. (2009) examine the use of ethics-related terms in $10-\mathrm{K}$ reports and use a binary variable that reflects the occurrence of ethics-related terms. A greater number of CSR topics are examined by Pencle and Mălăescu (2016) and Cannon et al. (2017). Based on 10-K reports the authors construct word lists that cover different areas of CSR. Topic-specific CSR disclosures are then measured as the frequency of the respective words in each report. The problem with such word lists is that they usually comprise a considerable number of words with ambiguous meanings that confound the validity of the measurement. Hummel et al. (2017) introduce a procedure to measure topic-specific CSR disclosures that draws on Hoberg and Maksimovic (2015). Instead of using simple word-count-based measures, they rely on the cosine similarity between each report and an automatically generated topic-specific vocabulary.

Our construction of topic-specific CSR disclosures measures follows the procedures introduced by Hoberg and Maksimovic (2015) and Hummel et al. (2017). Specifically, we measure the similarity of each annual report with respect to different CSR topics defined by the CSR directive and the corresponding guidelines for nonfinancial reporting (2017/C 2015/01). Our procedure is the following: For each annual report in our sample, we capture to 
what extent the report covers each of the following six topics: "environment", "social matters", "employee matters", "human rights", "anti-corruption" and "bribery". ${ }^{7}$ For each topic, we define a relevant search term that directly relates to the respective topics. Specifically, we use "ecology" for environmental matters $\left(\mathrm{T}_{\mathrm{ENV}}\right)$, "social" for social matters $\left(\mathrm{T}_{\mathrm{SOC}}\right)$, "employee" for employee matters $\left(\mathrm{T}_{\mathrm{EMPL}}\right)$, "human right" for human rights $\left(\mathrm{T}_{\mathrm{HR}}\right)$, "corruption" for anti-corruption $\left(\mathrm{T}_{\mathrm{CORR}}\right)$ and "bribery" for bribery $\left(\mathrm{T}_{\mathrm{BRIB}}\right)$. Next, we construct 20-word windows around the search terms that comprise the 9 words directly before and the 10 words directly after the search term. ${ }^{9}$ For each topic, we retrieve all the word windows that appear in the sample annual reports and aggregate them into topic vocabularies. We do this by using a common weighting term from the literature, term frequency inverse document frequency (tf-idf); see for instance Loughran and McDonald (2011, p. 1208; 2016). We then calculate the cosine similarity between the text in each annual report and our topic vocabularies to measure how similar (close) the report's vocabulary is to each topic-specific vocabulary. The cosine similarity is used to find similarities between pairs of documents (Crossno, Wilson, Shead, \& Dunlavy, 2011, p. 937) and is calculated as the inner product of two vectors, one describing the word usage in the annual report and the other describing the word usage in the topic vocabulary. This method compares the relative word frequencies across documents with score ranges between zero and one; if the score is one, the documents have the identical proportion of words, and if the score is zero, the documents have no similarities (Lang and Stice-Lawrence, 2015, pp. 113, 131). Thus, the higher the value of our CSR disclosures measure, the closer the reference document is to the topic-specific vocabulary. To compare different documents, cosine similarity has also been recently adopted

\footnotetext{
${ }^{7}$ Another approach to defining the CSR-related topics is to use the latent dirichlet allocation (LDA) (e.g. A. Huang, Lehavy, Zang, \& Zheng (2017)) to extract the topics from the annual reports. We experimented with the LDA, but the prevalence of CSR topics in annual reports was still too low to generate more than one distinct CSR-related topic.

${ }^{8}$ We also considered the term "environmental" but as our word lists reveals, the term is too broad in a companycontext.

${ }^{9}$ In the case of $\mathrm{T}_{\mathrm{HR}}$, the word windows comprise the 9 words that appear before and the 9 words that appear after the search term.
} 
in the finance and accounting literature. Specifically for comparing different accounting standards such as US GAAP and IFRS (Loughran and McDonald, 2016, pp. 1214-1215) as well as different textual characteristics, such as the quantity of disclosures, boilerplate, readability, and comparability between US and non-US firms' annual reports (Lang and Stice-Lawrence, 2015, p. 131).

Panel A of Table 2 provides an overview of the top twenty words in the retrieved twentyword windows thereby providing some intuition as to whether our word windows appropriately capture the respective topics. Based on the number of frequencies, the topicspecific CSR disclosures measure with respect to social matters $\left(T_{E M P L}\right)$ is most prevalent in the annual reports of the sample firms. It appears to primarily relate to employee-related topics as well as the composition of the management and board. Similarly, the topic social matters $\left(T_{S O C}\right)$ is also highly prevalent in the annual reports of the sample firms and appears to capture the social responsibility of the company. The frequency of the retrieved words for the topics human rights $\left(T_{H R}\right)$ and corruption $\left(T_{S O C}\right)$ are rather similar. The topic $T_{H R}$ appears to capture the discussion of human rights principles and policies in both the firm and the supply chain. The topics $T_{C O R R}$ and $T_{B R I B}$ capture similar content, although the search term "corruption" is much more prevalent $(18,136)$ in the annual reports than the search term "bribery" (7,334). Both topics refer to anti-corruption and anti-bribery risks, policies and codes of conduct including employee training and practices. The least frequent topic is ecology $\left(\mathrm{T}_{\mathrm{ENV}}\right)$, which is discussed in the context of the environment and sustainable development. ${ }^{10}$ Taken together, the retrieved words reveal that the topic vocabulary adequately captures the predefined topics. Additionally, we provide some examples for the

\footnotetext{
${ }^{10}$ A reason for the low occurrence could be the use of the search term "ecology"; however the term "environment" is too broad in the context of annual reports as our untabulated results confirm.
} 
20 -word windows in panel B. For a detailed description of the procedure to calculate the topic-specific disclosures measures, see Appendix II. ${ }^{11}$

Insert Table 2 about here

We argue that the construction of topic-specific vocabularies based on word windows is valid (since it is based on a single, unambiguous search term), objective (no subjective definitions of search terms) and replicable.

\subsection{Institutional Environment}

We draw on prior studies to identify the institutional variables we expect to be related to how capital markets perceive CSR disclosures. Specifically, we focus on CSR awareness and employee protection to assess the relevance of CSR in a country, and we focus on the legal environment and enforcement to assess the regulatory environment of each country. We draw on prior studies to identify the relevant variables (Cahan et al., 2016; De Villiers and Marques, 2016; Ernstberger et al., 2008; Isidro and Marques, 2015; Leuz et al., 2003; Wang and $\mathrm{Yu}, 2015$ ) and public CSR awareness (Cahan et al., 2016; Dhaliwal et al., 2011, 2014). Because several of these institutional variables are highly correlated with one another and thus cannot be simultaneously examined in a regression model, we perform a principal component analysis (PCA) with oblique Oblimin rotations ${ }^{12}$ to extract distinct factors. Additionally, the aggregation of the distinct score of the distinct measures has the advantage of capturing

\footnotetext{
${ }^{11}$ Prior to the textual analysis, we apply various standard pre-processing methods to the text. Specifically, we eliminate certain characters and divide the text into single tokens. Next, we exclude all numbers, stop words and the names of the sample firms. Finally, we apply a stemming algorithm to collapse the words down to their word stem (Porter, 1980). These procedures enhance the comparability of the corpora. For the textual analyses, we use Python, in particular the gensim and nltk packages.

${ }^{12}$ Because the underlying theoretical model does not assume that the constructs are uncorrelated, the oblique rotation method is the most suitable (Hair, Black, Babin, \& Anderson, 2010).
} 
similarities. Appendix III provides an overview of the institutional variables entered into the PCA. $^{13}$

For all of our measures we use yearly scores (if available) and average them over the whole sample period of nine years. Furthermore we construct an aggregated measure factor_inst for our robustness tests and calculate the row mean above all four factors.

The results from the PCA reveal four factors, which all have an eigenvalue greater than 1 . Our first institutional variable (factor_csr) measures a country's CSR awareness and society's attitude towards CSR. Specifically, the factor comprises the variables sustainable development (Sust_Dev) measuring a country's prioritization of sustainable development, the implementation of ethical practices (Eth_Pract), the perceived social responsibility of business leaders within a country (Soc_Resp) and the prioritization of environmental laws (Env_Laws). All four variables are retrieved from the IMD World Competitiveness Database (WCD) and based on annual surveys of executives' opinions resulting in rankings of countries' competitiveness in different areas, ranging from 0 to 10 . Our second institutional variable (factor_empl) measures the country-specific importance of employee protection. The variable is comprised of the variables ${ }^{14}$ Empl_Law (Botero, Djankov, La Porta, Lopez-DeSilanes, \& Shleifer, 2004), measuring a country's employment laws; Coll_Law (Botero et al., 2004), measuring a country's collective relations laws; and an anti self dealing index (ASDI, Djankov, La Porta, Lopez-de-Silanes, \& Shleifer, 2008), measuring the private control of selfdealing. All the variables range between 0 and 1 .

Our third institutional variable (factor_leg) captures a country's legal environment and is determined by the following variables: Social security laws index (SoSec_Law), measuring the strength of a country's social security systems and ranging from 0 to 1 (Botero et al.,

\footnotetext{
${ }^{13}$ For all our measures we use yearly scores (if available).

${ }^{14}$ For all variables a higher ranking indicates a better ranking, if not stated otherwise.
} 
2004); human rights index (HRI), measuring a country's human rights protection with a range from 0 to 100 (Humana, 1992); Rule of law (Rule_Law), measuring the extent to which agents have confidence in, and abide by, the rules of society (World Bank); voice and accountability (Voice_Acct), measuring the extent to which a country's citizen are able to select their government (World Bank); government effectiveness (Gov_Eff), measuring the quality of public services and policies (World Bank); and regulatory quality (Reg_Qual), measuring the perceptions of a government's ability to implement sound policies (World Bank). All of those variables range between -2.5 and 2.5 (Kraay, Kaufmann, \& Mastruzzi, 2010). Bribery and corruption (Brib_Cor), measuring the potential existence of bribery and corruption in each country (IMD WCD); Environmental performance index $(E P I)$ measuring a country's environmental performance (Yale Law School) and ranging between 0 and 100, Degree of journalistic freedom of a country (Jour_Free, Reporters without Borders) ranging between -100 and 0; Corruption Controls (Corr_Contr), measuring the perceptions about the extent to which public power is exercised for private gain (World Bank) and ranging between -2.5 and 2.5 and law and order (Law \& Order), measuring the strength of a country's legal system (ICRG) ranging from 0 to 6 .

Our last institutional variable (factor_enf) captures a country's governmental stability and public enforcement and is comprised of two variables: Gov_Stab, measuring a country's governmental stability (ICRG) and the public enforcement index, PEI, measuring strength of a country's public enforcement (Djankov et al., 2008). The former ranges from 0 to 12 , and the latter ranges from 0 to 1.

We expect our choice of country-level measures to expand the current literature in the context of CSR-disclosures. Specifically, we add a dimension for enforcement through the inclusion of the Anti Self Dealing Index, ASDI (Ernstberger et al., 2008) and the public enforcement index, PEI. In view of the mandatory inclusion of information about bribery and corruption 
based on the CSR directive, the consideration of Brib_Cor and Corr_Cor also seems appropriate. Additionally, whereas only Cahan et al. (2016) account for ecology by considering the environmental performance index, EPI, we add another dimension that is more closely linked to the legal strength of a country, namely, the importance of environmental laws with Env_Laws. Finally, we expand the variables measuring the strength of the legal environment and follow Ernstberger et al. (2008) by adding Law_Order; additionally, we include Gov_Stab.

We provide all the institutional variables for each country in Appendix IV. In the robustness section of the paper, we additionally examine institutional variables derived from the Hofstede database.

\section{Results}

\subsection{Descriptive Statistics}

Panel A of Table 3 reports the descriptive statistics for the variables used in equations (1) to (3). Our dataset comprises 3,961 observations for the first stage. For $P$ we observe an average value of 42 EUR, $B V E$ yields a mean of 22.11 EUR. The overall EPS range is from 0 to 43.46 EUR, with a mean value of 2.41. The mean values of the textual variables vary between 0.01 and 0.1 , with environment, social and employee matters showing the scores with the highest level of similarity. In Figure 1 we provide some evidence about the yearly evolution of our topic-specific CSR disclosures; the pattern of a yearly increase in CSR disclosures is evident. Thus, one-year studies may only provide limited insight and transferability of results.

We also provide descriptive statistics per country in Appendix V. 
Insert Figure 1 about here

Table 4 provides the bivariate Pearson correlation coefficients. As expected and in line with the value-relevance model based on Ohlson (1995), we find high and significant correlations between the book value for equity and share price as well as between earnings per share and the share price. With respect to the disclosures measures, the results reveal negative and significant correlation coefficients between all the textual variables and share price. As expected, we obtain highly positive correlations between the textual measures, indicating that a disclosure on one of the topics is often accompanied by firm disclosures on the other topics in annual reports. This finding is similar to other studies that use a similar methodology (Hummel et al., 2017).

Insert Table 4 about here

\subsection{Results on the Value Relevance of CSR Disclosures}

Table 5 reports the results for equations (1) and (2), where we regress prices on the book value of equity and earnings, both, per share as well as the respective topic-specific CSR disclosures measures $\mathrm{T}_{i}$ for the period before and after the announcement of the CSR directive. ${ }^{15}$ Our results show that all the textual variables convey new information to the market but that the effective direction depends on the observed period. For the period after the

\footnotetext{
${ }^{15}$ The results remain basically unchanged when we run the regression for the sample of observations that are included in stage 2 , i.e. $n=3,303$.
} 
announcement of the CSR directive all topic-specific disclosures show a negative and significant relationship, whereas only $T_{S O C}, T_{H R}$ and $T_{C O R R}$ show a significant and positive relationship for the period before the publication of the directive. Therefore, we find support for our first hypothesis postulating that topic-specific CSR disclosures provide significant information content to capital market participants. ${ }^{16}$ With respect to the size of the coefficients in the regression models the coefficients for $T_{S O C}, T_{E M P L}$ and $T_{H R}$ range between 200 and -100 , whereas they are higher for corruption and bribery amounting to -367 and -733 respectively. $B V E$ is approximately 0.95 and $E A R N 2.7$; also the adjusted $\mathrm{R}^{2}$ of approximately $95 \%$ is in line with the value relevance literature.

Insert Table 5 about here

Furthermore, our results not only show that the effect of CSR disclosures depends on the considered topic but also on the regulatory setting, specifically the issuance of the CSR directive. The period before the communication of the CSR directive is obviously purely voluntary; however, as soon as the European Union communicates about the CSR directive in 2014, companies anticipate the need for mandatory disclosures and prior results confirm the economic consequences of the issuance of the directive (Grewal et al., 2017). Thus, we consider the years 2014 and later as a semimandatory setting; before 2014, managers could choose which information to disclose. In such settings, managers provide information only if the marginal benefits of disclosures exceed the marginal costs (Verrecchia, 1983). However, one might also argue that, in a voluntary setting, managers can engage in opportunistic reporting to influence public perceptions and maintain the firms' legitimacy. Although a

\footnotetext{
${ }^{16}$ To control for the textual characteristics of the annual report we also include readability and tone in equations (1) and (2). The results (untabulated) remain unchanged. We also include financial characteristics such as size, leverage and profitability and our results remain stable.
} 
direct comparison of our results is difficult, we are in line with prior value relevance studies observing a positive relationship between firm-value and CSR disclosures in a purely voluntary setting (Cahan et al., 2016; Clarkson et al., 2013; Dhaliwal et al., 2011, 2014; Dhaliwal et al., 2012; Plumlee et al., 2015). For the period after the announcement of the CSR directive we find a negative relationship for all the variables, indicating that capital market participants may consider that information costly. Such a negative effect can be the result of costly CSR activities, as stated by Vance (1975) and Ullmann (1985) for example. One possible interpretation is that capital markets participants expect companies to either engage in costly CSR activities for the sake of the CSR directive or that the disclosures and preparation of the respective information is costly. This line of reasoning is in line also with Dorfleitner, Halbritter, \& Nguyen (2015) who recently suggested that although overall ESG or KLD values may be positively related to financial performance, the real effect of CSR activities on financial performance depends on the importance of the theme behind the considered company and the relevant cost.

\subsection{Results on the Role of the Institutional Environment}

Based on our panel results that reveal significant results for all $T_{i}$, we investigate all six CSR topics. Table 6 provides descriptive results with respect to the incremental value relevance of the CSR topics based on the pooled regressions of equations (1) and (2). ${ }^{17}$ Column one shows descriptives (i.e. mean, standard deviation and median) for the adjusted $\mathrm{R}^{2}$ of the base model (i.e., equation 1), while the remaining columns report the adjusted $\mathrm{R}^{2}$ of the nested models, including the disclosures measures for the respective CSR topics. Over a sample of 374 firms the average $\mathrm{R}^{2}$ for the base model is $49.43 \%$ while the incremental $\mathrm{R}^{2}$ on average amounts to $62 \%$; thus, the inclusion of topic-specific CSR measures increases the mean adjusted $\mathrm{R}^{2}$ of the

\footnotetext{
${ }^{17}$ When comparing the results of the panel, it has to be considered that since we require at least 8 observations per firm to be included in our pooled regressions, our sample is reduced to 3,303 firm-year observations, i.e. 374 firms.
} 
base model, indicating the incremental value relevance of adding topic-specific CSR disclosures.

Insert Table 6 about here

Based on the $R_{\text {incr }}^{2}\left(T_{i}\right)$ reported in Table 6 we analyze how the incremental value relevance is shaped by the institutional environment. Our approach of splitting CSR disclosures into different topics provides further insights into the debate: the results are shown in Table 7 and reveal a negative and significant relationship between factor_csr as well as factor_empl and the incremental value-relevance that is provided by the textual measures. For the relationship between factor_leg and factor_enf, our results show a positive and significant coefficient for some topic-specific CSR disclosures. Thus, we find support for hypotheses H2 a), b), c) and d).

We find a negative relationship between factor_csr as well as factor_empl and CSR disclosures for all CSR topics. Therefore, if managers perceive that a country prioritizes CSR with respect to sustainable development through ethical practices in companies, socially responsible business leaders and decent environmental regulation, the incremental value relevance of topic-specific CSR disclosures is reduced. Thus, strong perceived compliance with CSR and employee protection on a country level reduces the incremental value relevance and thus the importance of supplementary information for capital market participants with respect to all the underlying topics. This finding also supports the reasoning of Matten and Moon (2008), specifically the implicit-explicit framework: if CSR awareness and employee protection are important on a country-level, companies do not need to address these topics explicitly, and thus, the incremental value relevance for capital market participants is limited. Companies cannot differentiate themselves from other companies through disclosures, and 
thus, report implicitly. This result is especially relevant for standard setters with regard to enlarging the mandate for mandatory CSR reporting.

We find a positive and significant relationship between factor_leg, measuring the strength of the legal environment for three topics, including human rights, corruption and bribery. Thus, for CSR information regarding environmental, social and employee matters, the strength of the legal system is not incrementally value relevant, whereas with regard to human rights, corruption and bribery, the strength of the legal environment increases the incremental value relevance. Thus, if the country-specific legal environment is stronger, the explanatory power of adding topic-specific CSR disclosures with respect to human rights, corruption and bribery increases. Bearing in mind the fact that the topics human rights, corruption and bribery exhibit the lowest similarity scores (see Figure 1), this result is interesting, providing evidence that for topics that are less common, on a national level, institutions play an important role in increasing their explanatory power.

In line with legal strength, the factor accounting for the level of enforcement factor_enf, is also positive for all the topics, revealing a significant relationship for environment, social, employee matters, and human rights. Specifically the results indicate that the level of enforcement do not impact the incremental value relevance for the topics corruption and bribery. Thus, for more prevalent topics based on higher similarity scores, the level of enforcement is more important. Our findings on the factors factor_leg and factor_enf are generally in line with those of Wang and $\mathrm{Yu}$ (2015), but are contrary to those of Core et al. (2015), and Dhaliwal et al. (2012). However, note that these other studies often rely on composite measures for the institutional environment.

With respect to the explanatory power of our models, for environment the $\mathrm{R}^{2}$ is the smallest only amounting to $5.7 \%$; social and employee matters exhibit the highest explanatory power of more than $9 \%$. 
Taken together, our results show that especially the CSR awareness impacts the importance of topic-specific CSR disclosures. The higher the prioritization of CSR on a country-level, the lower the incremental value relevance resulting from the addition of topic-specific CSR disclosures. For legal strength and the level of enforcement we confirm the opposite relationship, showing that for certain disclosures, the value relevance increases with legal strength or the level of enforcement. Depending on the topic under consideration, it is either the legal strength or the level of enforcement which drives the incremental relevance; for those topics showing smaller similarity scores, the legal strength is significant, for those with higher scores it is the level of enforcement. Finally, only for the topic human rights all four factors are significant.

Insert Table 7 about here

\section{Further Analyses}

\subsection{Alternative Model Specifications}

Due to measurement differences with respect to CSR disclosures proxies, clear comparisons with other studies are often difficult. However, in order to provide some robustness checks with respect to Dhaliwal et al. (2012), Dhaliwal et al. (2011), Dhaliwal et al. (2014), we also consider the issuance of a stand-alone CSR report as a proxy for CSR disclosures. Thus, we include an additional variable CSR_Report that takes on the value of 1 if the firm publishes a separate CSR report in the respective year and 0 otherwise. ${ }^{18}$ Our results are in line with Dhaliwal et al. (2011, 2014); Dhaliwal et al. (2012) showing a positive and significant

\footnotetext{
${ }^{18}$ CSR_Report is measured based on hand-collected data; the reports were either gathered from the company websites or directly requested from the companies by email. Our results show that approximately $45 \%$ of the companies provide a CSR report.
} 
relationship for the baseline model at a 10\% significance level (untabulated). However, when considering both the respective topic-specific CSR disclosures and the issuance of a separate CSR report, our main results remain unchanged. Nevertheless, in this case CSR_Report is not significant. Thus, our results show that considering the mere publication of a CSR report is not enough to measure CSR disclosure. We need to account for the nature of the CSR disclosures and topic-specific measures are the main drivers of the results and thus, extend the view in important ways.

Furthermore, the literature shows that CSR performance also has an impact on CSR disclosures (Al-Tuwaijri et al., 2004; Hummel and Schlick, 2016). To account for the results confirming this relationship we include two measures of the sustainability performance of a firm. First, a dummy, DJSI, equal to 1 if the company is noted in the Dow Jones Sustainability Index (DJSI) and second, a4ir, the ESG score provided by Asset 4 Thomson Reuters, considers the overall ESG performance of the respective company. Concerning CSR performance, the overall asset 4 score denoted by a4ir for the considered sample is 78.88 on average over the whole considered time horizon and $24 \%$ of the sample companies are included in the DJSI (see Appendix VI). Both our CSR performance measures are positive and significant (untabulated) and our results for the topic-specific CSR disclosures remain largely unchanged, except that, for the former, environment and social matters are no longer significant for the pre-directive period, and for the latter, social matters and corruption do not longer show a significant relationship for the period before the directive. Thus, especially our negative coefficients for the post-directive period appear to be robust.

We also conduct a number of additional analyses to investigate the robustness of our findings in the second stage. First, to rule out the impact of firm-specific factors on our findings, we rerun our regressions for equation (3), including additional control variables for firm-level characteristics, particularly firm size (logarithm of total revenues), firm profitability (return on 
assets) and firm leverage (ratio of debt to total assets) and firm CSR performance (DJSI and a4ir). Due to missing values on some of the control variables, our sample is reduced based on the availability of the underlying variables (see Table 3 for the number of observations per variable). The descriptives for the financial characteristics can be found in Appendix VI. The the average profitability is $8.8 \%$, leverage is on average $13.91 \%$.

Our results are robust to the inclusion of firm-level characteristics. More interestingly, the results show that size as well as profitability have a negative and significant impact on the incremental value relevance for all the considered topics. The larger and more profitable the firm is, the less important CSR-disclosures are. This result is remarkable in the context of the CSR directive, since the directive mandates only that large companies publish this information. Leverage is positive and significant for social and employee matters as well as for corruption, indicating that for highly leveraged firms those topics increase the incremental value relevance of disclosures.

Insert Table 8 about here

For the inclusion of CSR performance the results reveal that interestingly the impact depends on the underlying measure. DJSI is positive and significant for all topic-specific CSR disclosures, indicating that mere inclusion in the index increases the explanatory power of the topic-specific CSR disclosures in general. However, this result goes at the expense of the two factors accounting for the legal environment and employee protection for environmental matters, human rights, corruption and bribery. The inclusion of a4ir is not significant for any topic and does not impact the results. Taken together, the findings for CSR performance also show that the inclusion in the index increases the incremental value relevance of topic- 
specific CSR disclosures, and not a4ir. This is especially interesting for preparers of CSR information.

Insert Table 9 about here

Finally, we rerun the pooled regression models (1) and (2) including CSR performance. Our results for the institutional factors remain largely unchanged. Only for employee matters and human rights does the relationship change significantly and for corruption and bribery factor_enf is positive and significant if a 4ir is included (untabulated).

\subsection{Textual Analysis}

One could argue that our disclosure measures are biased due to other textual characteristics. Specifically, prior research shows that readability is positively associated with earnings $(\mathrm{Li}$, 2008), investment efficiency (Biddle et al., 2009), trading volume (Miller, 2010), lower analyst following (Lehavy et al., 2011) and lower earnings management (Lo, Ramos, \& Rogo, 2017). With respect to tone, there is empirical evidence that investors react more strongly to pessimistic analyst reports (A. Huang, Zang, \& Rong, 2014). Allee and DeAngelis (2015) find that analysts and investors respond more negatively to firm disclosures when negative tone is more pervasive and more positively when positive tone is more pervasive. Readability refers to how easily the reader can grasp the content of a text while tone refers to the attitude of the text. The literature typically refers to the Fog Index, the Flesch-Kincaid and the Flesch Reading Ease as typical measures of readability. These measures are calculated based on the average number of words per sentence and the average number of syllables per word. Following De Franco, Hope, Vyas, \& Zhou (2015) we create an aggregate measure of readability based on the Fog Index, the Flesch-Kincaid, and the Flesch Reading Ease. More 
precisely, discl_readability is measured based on the average of the percentile ranks for each component, divided by 100 and multiplied by $(-1)$ to enhance the intuitive interpretation of the measure. ${ }^{19}$ Thus, higher values in discl_readability reflect a better readability of the text. With respect to tone, we use the word list provided by Loughran and McDonald (2011) to identify positive and negative words in the annual reports. This word list has been specifically designed for accounting research. Our measure discl_tone is then calculated as the frequency of positive words (relative to all words) minus the frequency of negative words (relative to all words).

With respect to the textual control variables discl_readability has a mean value of -0.5067 indicating that all three underlying readability measures are consistent on average. The underlying Gunning Fog Index is 13 indicating that on average 13 years of education are needed to grasp the content of the annual reports at one. The tone of the annual reports is positive on average and amounts to 0.0023 on average. It is lower than for CSR reports (Hummel et al., 2017) and earnings press releases (X. Huang, Teoh, \& Zhang, 2014), which makes sense because annual reports are legal documents. Compared to $8-\mathrm{K}$ filings the tone is more positive (Henry and Leone, 2016).

We include both measures and rerun the regressions for equations (1) to (3). Both measures are not significant in stage 1, i.e. equations (1) and (2) and our results remain unchanged (untabulated). This finding again strengthens our approach to using topic-specific measures; and argues in favour that these measures capture more than the general textual proxies do.

With reference to the incremental value relevance our results are displayed in Table 10. Tone is negative and significant for all the topics indicating, that our CSR disclosures - when

\footnotetext{
${ }^{19}$ To obtain consistent interpretations of discl_readability, we use the (101-percentile rank) for Flesch Reading Ease.
} 
positive in tone - has a negative impact on the incremental value relevance. With respect to readability, only employee matters and human rights show a significant and positive relationship, indicating, that better readability increases the explanatory power of the inclusion of the CSR disclosures. Interestingly, this result is especially the case for peoplerelated variables.

Insert Table 10 about here

Because our results with respect to the measurement of topic-specific CSR disclosure could also be biased because of boilerplate issues we perform two further analyses. First, we calculate similarity scores for standard boilerplate content (standard_boilerplate) and industryspecific boilerplate content (industry_boilerplate) and include the two variables as additional controls in equation (1). Our results remain unchanged (untabulated).

Second, in order to eliminate industry- and yearly boilerplate-effects we calculate an alternative measure for our topic-specific CSR disclosure by regressing our similarity score on the two boilerplate measures and use the resulting residuals as topic-specific disclosure. This allows us to consider a non-boilerplate measure, including only company-specific similarities to the respective topic. Our results (untabulated) remain robust only for the negative relationship between share price and $\mathrm{T}_{\mathrm{SOC}}, \mathrm{T}_{\mathrm{EMPL}}, \mathrm{T}_{\mathrm{HR}}, \mathrm{T}_{\mathrm{CORR}}$ and $\mathrm{T}_{\mathrm{BRIB}}$. Thus, the negative coefficient could be an indication that especially context-specific information provided by companies exhibit a negative relationship with share price. Our results for stage 2 remain largely unchanged. 


\subsection{Institutional Variables}

To provide some comparability with existing studies we aggregate our four institutional factors to one factor and in line with Cahan et al. (2016) find a negative and significant impact of the institutional strength (see Table 11). However, through the consideration of four distinct factors, separately accounting for the CSR awareness, employee protection, the legal strength and the level of enforcement, we are able to disentangle the overall effect; as our results show this is necessary as different effects come into place and act in different directions. We also investigate a direct link between the institutional environment and CSR performance on the incremental value relevance of the CSR disclosures. Thus, we consider the aggregated measure of the institutional environment and interact it with DJSI. Our results (see Table 12) show, that the coefficient does not differ depending on the CSR performance and is negative and significant for both, fact_inst and fact_inst ${ }^{*} D J S I$. Separating our sample in above and below median based on the a 4 ir score does not show any significance at all.

Insert Table 11 and 12 about here

Furthermore, following Hope (2003) we account for the national culture on a country-level and consider the dimensions provided by Hofstede (1983). We rerun our second stage analysis for every dimension separately. Regarding power of distance (POD), accounting for how a society handles inequalities among people, and individualism (IND), reflecting whether people's self-image is defined by "I" or "we", the results exhibit a positive and significant relationship for all topics, except environment. In contrast the relationship for all topics, except environment, is negative for the remaining dimensions including masculinity, measuring a society's level of competitiveness, and the uncertainty avoidance index, expressing the degree to which the members of a society feel uncomfortable with uncertainty 
and ambiguity. Interestingly, and in accordance with our previous results the topic environment is not shaped by cultural dimension provided by Hofstede. Our results are broadly in line with Cahan et al. (2016); and Hope (2003), except for POD, where one would expect a negative relationship.

\section{Conclusion}

This study investigates the value relevance of topic-specific CSR information in firms' annual reports and how it is shaped by the national institutional environment. We use textual analysis to investigate firms' disclosures in their annual reports on predefined CSR topics, namely, environment, employee matters, social matters, human rights, corruption and bribery. Specifically, we follow the methodology introduced by Hoberg and Maksimovic (2015) and Hummel et al. (2017) and extract twenty-word windows to construct a topic vocabulary for each CSR topic. We then measure the similarity between each annual report and the topic vocabularies. For a sample of 3,961 firm-year observations, we show that firms' disclosures on the respective topics are indeed considered to provide informational content to capital markets. To analyze the incremental value relevance of the CSR topics, we consider the effect the institutional environment has on the increase in explanatory power, specifically the adjusted $\mathrm{R}^{2}$. Based on the prior literature, we focus on four institutional factors: CSR awareness, employee protection, legal environment and enforcement. Our results indicate that CSR awareness and employee protection have a negative effect on explanatory power for the inclusion of environmental, social and employee matters, respect for human rights, and corruption. This finding is consistent with the implicit-explicit framework (Matten and Moon, 2008) framing that CSR disclosures are more implicit if there is more country-specific regulation with respect to the considered CSR topics. For the legal environment and enforcement, we find an indication of an increase in explanatory power. However, in our robustness section, we provide evidence that both the financial and textual characteristics of 
the annual report are also drivers of the information content incremental to adding topicspecific CSR disclosures measures.

As with all studies, this study is also subject to some limitations. While we are particularly interested in how the capital market perceives firms' disclosures on CSR topics in annual reports, one may argue that firms provide CSR information through various disclosures channels, including separate CSR reports and company web sites. Although our additional analyses reveal that the issuance of a stand-alone CSR report is not value relevant, if topicspecific CSR disclosures are added to the model, future research might examine the combined impact of both CSR disclosures in annual reports and stand-alone CSR reports. Such an analysis would also account for the growing trend towards integrated reporting. Second, this study is an association study and as such do not provide evidence for a causal relationship. Specifically, for the first stage of our study, we cannot completely rule out the possibility of reverse causality. Indeed, as revealed by Lys, Naughton, \& Wang (2015), better performing firms might use CSR disclosure to signal their superior performance. Future studies might therefore choose a setting that allows for clear identification of the causal effects. Finally, the usual weaknesses of textual analysis apply. In particular, our sample consists of reports provided by firms located in different European countries in which English may be only the business language, not the native language and we therefore cannot completely rule out the fact that translation issues might impact the textual characteristics. However, as our focus of inquiry does not rely on purely textual characteristics such as readability and tone, but rather on topic-specific disclosures, we are confident that our results are not biased due to translation issues. Instead, this study applies a novel methodology in textual analysis to examine topicspecific disclosures that might be of interest to other researchers, both in the area of CSR accounting and in other accounting areas. 


\section{APPENDIX I Variable Description}

\begin{tabular}{|c|c|}
\hline Variable & Description \\
\hline \multicolumn{2}{|c|}{ Main Variables } \\
\hline$P$ & Share Price at fiscal year end \\
\hline$B V E$ & $\begin{array}{l}\text { Book value of equity is common equity at fiscal year end, divided by the } \\
\text { number of outstanding shares }\end{array}$ \\
\hline$E A R N$ & Earnings per share at fiscal year end \\
\hline $\mathrm{T}_{\mathrm{ENV}}$ & $\begin{array}{l}\text { tf-idf similarity of the firm's disclosures in the annual report with a } \\
\text { vocabulary that reflects disclosures with respect to environmental } \\
\text { matters; the search term is "ecology" }\end{array}$ \\
\hline $\mathrm{T}_{\mathrm{SOC}}$ & $\begin{array}{l}\text { tf-idf similarity of the firm's disclosures in the annual report with a } \\
\text { vocabulary that reflects disclosures with respect to social matters; the } \\
\text { search term is "social" }\end{array}$ \\
\hline $\mathrm{T}_{\mathrm{EMPL}}$ & $\begin{array}{l}\text { tf-idf similarity of the firm's disclosures in the annual report with a } \\
\text { vocabulary that reflects disclosures with respect to employee matters, } \\
\text { the search term is "employee" }\end{array}$ \\
\hline $\mathrm{T}_{\mathrm{HR}}$ & $\begin{array}{l}\text { tf-idf similarity of the firm's disclosures in the annual report with a } \\
\text { vocabulary that reflects disclosures with respect to respect to human } \\
\text { rights; the search term is the bigram "human right" }\end{array}$ \\
\hline $\mathrm{T}_{\mathrm{CORR}}$ & $\begin{array}{l}\text { tf-idf similarity of the firm's disclosures in the annual report with a } \\
\text { vocabulary that reflects disclosures with respect to corruption; the search } \\
\text { term is "corruption" }\end{array}$ \\
\hline $\mathrm{T}_{\mathrm{BRIB}}$ & $\begin{array}{l}\text { tf-idf similarity of the firm's disclosures in the annual report with a } \\
\text { vocabulary that reflects disclosures with respect to bribery; the search } \\
\text { term is "bribery" }\end{array}$ \\
\hline
\end{tabular}

Source of data

Bloomberg

Datastream

Datastream

textual

analysis

textual

analysis

textual

analysis

textual

analysis

textual

analysis

textual

analysis

see table 2

Institutional factor resulting from a PCA on the institutional variables as reported in Table 2. Results from the factor analysis are reported in table II in the appendix

factor_csr Institutional factor resulting from a PCA on the institutional variables as reported in Table 2. Results from the factor analysis are reported in table II in the appendix

factor_empl Institutional factor resulting from a PCA on the institutional variables as reported in Table 2. Results from the factor analysis are reported in table II in the appendix

factor_gov Institutional factor resulting from a PCA on the institutional variables as reported in Table 2. Results from the factor analysis are reported in table II in the appendix

\section{Control Variables}

discl_tone

(number of positive words - number of negative words)/number of total words of the voluntary CSR disclosures; word lists are defined according to the word list provided by Loughran and McDonald (2011); higher values reflect a more positive tone

discl_readability average mean of the percentile ranks for the Fog Index, and the FleschKincaid and the (101 - percentile ranks) for the Flesch-Reading-Ease, divided by 100 , multiplied with (-1); higher values reflect higher readability textual

analysis

textual analysis 
leverage financial leverage of the firm measured as total debt divided by total

datastream assets at fiscal year end

size firm size measured as the logarithm of the revenues at fiscal year end

datastream

profitability

Profitability is measured as EBIT divided by total assets at fiscal year

datastream

DJSI end

Dummy variable that equals 1 if the company was a constituent of the Dow Jones Sustainability index between 2010 and 2016

DJSI 


\section{APPENDIX II Details on the construction of the topic-specific disclosures measures}

\section{General procedure (analogous to Hummel et al. (2017) and Hoberg and Maksimovic (2015))}

1. Let $\mathrm{N}$ denote the number of unique words in the entire corpus.

2. For each topic, we query for pre-defined search term(s) across all documents (e.g. query for "bribery" for the topic-specific disclosures measure on bribery)

3. For each query load, we retrieve twenty-word windows around the identified search terms. The twenty-word windows include the nine to ten words preceding the query term and the nine words following the query term.

4. For each topic, we aggregate all retrieved twenty-word windows into a topic vocabulary. The topic vocabulary includes all words that appear in all retrieved twenty-word windows for each topic.

5. For each topic, we define an N-vector search that is filled with the term-frequencyinverse-document-frequency (tf-idf) of each word in the topic vocabulary corresponding to each of the $\mathrm{N}$ elements.

6. For each firm $i$ in each year $t$, we define an $\mathrm{N}$-vector text $t_{i, t}$ that is filled with the tf-idf for each word in firm i's annual report in year $t$ corresponding to each of the $\mathrm{N}$ elements. $^{20}$

7. For each element of the $\mathrm{N}$-vector, the inverse-document-frequency (idf) is calculated as:
(1) idf $=\log _{2} \frac{n}{f}$ where
$\mathrm{n}$ : number of all documents
$\mathrm{f}$ : number of documents in which the word appears

8. For each element of the $\mathrm{N}$-vector search, the tf-idf is calculated as the product of the number of times the word appears in the topic vocabulary and the idf.

9. For each element of the N-vector text $t_{i, t}$, the tf-idf is calculated as the product of the number of times the word appears in the annual report of firm $i$ in year $t$ (i.e. the term frequency) and the idf.

10. To neutralize the impact of document length, we normalize the N-vector search as:

$$
\text { (2) search_norm }=\frac{\text { search }}{\sqrt{\text { search } \cdot \text { search }}}
$$

11. Similarly, we normalize the $\mathrm{N}$-vector text $\mathrm{t}_{\mathrm{i}, \mathrm{t}}$ :

$$
\text { (3) } \text { norm }_{i, t}=\frac{\text { text }_{i, t}}{\sqrt{\text { text }_{i, t} \cdot \text { text }_{i, t}}}
$$

12. To obtain the similarity between the firm i's CSR disclosures in its annual report in year $\mathrm{t}$ and the topic vocabulary, we calculate similarity $\mathrm{i}_{\mathrm{i}, \mathrm{t}}$ as the cosine similarity (i.e., the dot product) between norm $_{i, t}$ and search_norm.

(4) similarity $_{i, t}=$ norm $_{i, t} \cdot$ search_norm $_{-}$

\footnotetext{
${ }^{20}$ Hoberg and Maksimovic (2015) simply use a vector of word counts (i.e. the term frequency) instead of the tfidf. In contrast, the tf-idf incorporates a term weighting procedure (i.e., the inverse document frequency) and adjusts a word's weight based on how (un)usual the word is. It thus reflects the importance of a word in a specific document relative to the importance of that word in the entire corpus. The more unusual the word, the higher the weight (Loughran and McDonald, 2016).
} 
1. Consider three texts which - after applying the pre-processing methods - can be described according to the following word lists:

text_1 = ['community', 'impact', 'involve', 'compliance', 'corruption']

text_2 $=$ ['ethics, 'community', 'involve, 'impact']

text_3 = ['ethics', 'corruption', 'compliance', 'impact', 'bribery']

2. Consider the following training set (as a result of the search query):

search $=$ ['corruption', 'bribery']

3. The corpus is given as:

corpus $=[$ 'corruption', 'bribery', 'ethics', 'compliance', 'involve', 'impact', 'community']

4. The inverse-document-frequency for each word corresponds with:

$$
\begin{array}{ll}
\mathrm{W}_{\text {corruption }} & =0.5850 \\
\mathrm{~W}_{\text {bribery }} & =1.5850 \\
\mathrm{~W}_{\text {ethics }} & =0.5850 \\
\mathrm{~W}_{\text {compliance }} & =0.5850 \\
\mathrm{~W}_{\text {involve }} & =0.5850 \\
\mathrm{~W}_{\text {impact }} & =0.0000 \\
\mathrm{~W}_{\text {community }} & =0.5850
\end{array}
$$

5. The tfidf-vector for the training set and each text corresponds with:

$$
\begin{aligned}
& \text { search }=[0.5850,1.5850,0.0,0.0,0.0,0.0,0.0] \\
& \text { text_1 }=[0.5850,0.0,0.0,0.5850,0.5850,0.0,0.5850] \\
& \text { text_2 }=[0.0,0.0,0.5850,0.0,0.5850,0.0,0.5850] \\
& \text { text_3 }=[0.5850,1.5850,0.5850,0.5850,0.0,0.0,0.0]
\end{aligned}
$$

6. The normalized tfidf-vector for the training set and each text corresponds with:

$$
\begin{aligned}
& \text { norm_search }=[0.3462,0.9381,0.0,0.0,0.0,0.0,0.0] \\
& \text { norm_text_1 }=[0.5,0.0,0.0,0.5,0.5,0.0,0.5] \\
& \text { norm_text_2 }=[0.0,0.0,0.5774,0.0,0.5774,0.0,0.5774] \\
& \text { norm_text_3 }=[0.311,0.8426,0.311,0.311,0.0,0.0,0.0]
\end{aligned}
$$

7. The cosine similarity for each text corresponds with:

similarity_text $1=$ norm_search $\cdot$ norm_text_1 $=0.1731$

similarity_text_2 $=$ norm_search $\cdot$ norm_text_2 $=0.0000$

similarity_text_3 $=$ norm_search $\cdot$ norm_text_3 $=0.8981$ 
APPENDIX III Overview of national-level institutional variables

\begin{tabular}{|c|c|c|}
\hline Variable & Variable measurement & Source \\
\hline Empl_Law & $\begin{array}{l}\text { Employment laws based on alternative employment contracts, cost } \\
\text { of increasing hours worked, cost of firing workers and dismissal } \\
\text { procedures }\end{array}$ & Botero et al. (2004) \\
\hline SoSec_Law & $\begin{array}{l}\text { Social security laws Index based on old age, disability, and death } \\
\text { benefits, sickness and health benefits and unemployment benefits }\end{array}$ & Botero et al. (2004) \\
\hline Coll_Law & $\begin{array}{l}\text { Collective relations laws based on labour union power and collective } \\
\text { disputes }\end{array}$ & Botero et al. (2004) \\
\hline $\begin{array}{l}\text { Human Rights } \\
\text { Index (HRI) }\end{array}$ & $\begin{array}{l}\text { Human rights laws, considering human rights protection with higher } \\
\text { scores indicating better human rights protection (HRI) }\end{array}$ & Humana (1992) \\
\hline Rule_Law & $\begin{array}{l}\text { Extent to which agents have confidence in, and abide by, the rules of } \\
\text { society }\end{array}$ & World Bank \\
\hline Voice_Acct & $\begin{array}{l}\text { Extent to which a country's citizen are able to select their } \\
\text { government and voice other concerns }\end{array}$ & World Bank \\
\hline Govt_Eff & $\begin{array}{l}\text { Perceptions of the quality of public services and polices, and the } \\
\text { government to promote such policies }\end{array}$ & World Bank \\
\hline Reg_Qual & $\begin{array}{l}\text { Perceptions of the government's ability to formulate and implement } \\
\text { sound policies }\end{array}$ & World Bank \\
\hline Corr_Contr & $\begin{array}{l}\text { Captures perceptions of the extent to which public power is } \\
\text { exercised for private gain }\end{array}$ & World Bank \\
\hline Sust_Dev & $\begin{array}{l}\text { Sustainable development priority: "Sustainable development is a } \\
\text { priority in countries." }\end{array}$ & $\begin{array}{l}\text { IMD World } \\
\text { Competitiveness } \\
\text { Database (WCD) }\end{array}$ \\
\hline Eth_Pract & $\begin{array}{l}\text { Ethical practice implementation: "Ethical practices are implemented } \\
\text { in companies" }\end{array}$ & IMD WCD \\
\hline Soc_Resp & $\begin{array}{l}\text { Social responsibility: "The social responsibility of business leaders } \\
\text { is high" }\end{array}$ & IMD WCD \\
\hline Brib_Cor & Bribery and corruption: "Bribery and corruption do not exist" & IMD WCD \\
\hline Env_Laws & $\begin{array}{l}\text { Environmental laws: "Environmental laws and compliance do not } \\
\text { hinder the competitiveness of businesses" }\end{array}$ & IMD WCD \\
\hline$E P I$ & Environmental Performance Index ${ }^{21}$ & Yale Law School \\
\hline Jour_Free & Degree of journalistic freedom & $\begin{array}{l}\text { Reporters without } \\
\text { borders }\end{array}$ \\
\hline Law \& Order & $\begin{array}{l}\text { Strength and impartiality of the legal system and the popular } \\
\text { observance of the law }\end{array}$ & ICRG \\
\hline Gov_Stab & $\begin{array}{l}\text { Measure of the government's ability to carry out its declared } \\
\text { programs and to stay in office }\end{array}$ & ICRG \\
\hline $\begin{array}{l}\text { Anti Self-Dealing } \\
\text { Index (ASDI) }\end{array}$ & Ex-ante and ex-post private control of self-dealing & $\begin{array}{l}\text { Djankov et al } \\
(2008)\end{array}$ \\
\hline $\begin{array}{l}\text { Public } \\
\text { Enforcement Index } \\
\text { (PEI) }\end{array}$ & Strength of public enforcement of self-dealing & $\begin{array}{l}\text { Djankov et al } \\
(2008)\end{array}$ \\
\hline
\end{tabular}

${ }^{21}$ Multiplied by (-1) for consistency. Higher values thus reflect better environmental performance. 
APPENDIX V Descriptives per Country

\begin{tabular}{|c|c|c|c|c|c|c|c|c|c|c|c|c|c|c|c|c|}
\hline \multicolumn{17}{|c|}{ Panel A: Descriptive Statistics of the Main Variables } \\
\hline & $\mathrm{AT}$ & $\mathrm{BE}$ & $\mathrm{CH}$ & DE & DK & ES & FI & FR & GB & IE & IT & LU & NL & NO & $\mathrm{PT}$ & SE \\
\hline$P$ & 20.3865 & 53.6977 & 201.570 & 52.0220 & 74.3248 & 13.7301 & 19.7016 & 50.7746 & 11.3449 & 23.4918 & 8.9631 & 29.4834 & 29.8210 & 13.4309 & 8.6492 & 12.7885 \\
\hline$B V E$ & 18.8698 & 39.1879 & 89.6147 & 39.3868 & 33.1958 & 7.5763 & 10.2575 & 30.0781 & 5.1563 & 7.9811 & 5.9755 & 12.9588 & 16.0371 & 7.8434 & 3.2042 & 9.2001 \\
\hline$E A R N$ & 1.6305 & 2.8325 & 11.2258 & 3.4894 & 3.1399 & 0.9163 & 1.2851 & 2.8055 & 0.7512 & 1.1120 & 0.5404 & 1.4963 & 1.6050 & 0.9722 & 0.3560 & 0.9219 \\
\hline Post & 0.3443 & 0.3824 & 0.3647 & 0.3783 & 0.3824 & 0.3431 & 0.3306 & 0.3428 & 0.3556 & 0.3380 & 0.3581 & 0.4000 & 0.3874 & 0.3421 & 0.3600 & 0.3553 \\
\hline Score & 0.0426 & 0.0490 & 0.0541 & 0.0599 & 0.0479 & 0.0607 & 0.0760 & 0.0820 & 0.0669 & 0.0627 & 0.0655 & 0.0462 & 0.0692 & 0.0646 & 0.0670 & 0.0678 \\
\hline$T_{E N V}$ & 0.0642 & 0.0760 & 0.0871 & 0.0960 & 0.0743 & 0.0825 & 0.0960 & 0.1012 & 0.1078 & 0.0952 & 0.0955 & 0.0768 & 0.1050 & 0.0962 & 0.0918 & 0.0951 \\
\hline$T_{S O C}$ & 0.0430 & 0.0654 & 0.0701 & 0.0685 & 0.0629 & 0.0718 & 0.0754 & 0.0982 & 0.0832 & 0.0733 & 0.0740 & 0.0608 & 0.0849 & 0.0731 & 0.0698 & 0.0788 \\
\hline$T_{E M P L}$ & 0.0603 & 0.0764 & 0.0932 & 0.0901 & 0.0823 & 0.0696 & 0.0961 & 0.1016 & 0.1190 & 0.1024 & 0.0886 & 0.0772 & 0.1108 & 0.0988 & 0.0701 & 0.1049 \\
\hline$T_{H R}$ & 0.0154 & 0.0235 & 0.0273 & 0.0282 & 0.0280 & 0.0370 & 0.0377 & 0.0379 & 0.0315 & 0.0252 & 0.0280 & 0.0222 & 0.0384 & 0.0350 & 0.0316 & 0.0365 \\
\hline$T_{\text {CORR }}$ & 0.0074 & 0.0114 & 0.0130 & 0.0149 & 0.0112 & 0.0168 & 0.0177 & 0.0183 & 0.0175 & 0.0131 & 0.0169 & 0.0116 & 0.0185 & 0.0210 & 0.0146 & 0.0196 \\
\hline$T_{B R I B}$ & 0.0048 & 0.0077 & 0.0090 & 0.0096 & 0.0076 & 0.0094 & 0.0112 & 0.0104 & 0.0154 & 0.0104 & 0.0106 & 0.0091 & 0.0129 & 0.0130 & 0.0081 & 0.0115 \\
\hline Size & 15.0547 & 15.1867 & 15.3090 & 16.4756 & 14.7054 & 15.6334 & 15.3421 & 16.0617 & 14.9532 & 15.1095 & 15.6171 & 15.2222 & 15.8196 & 15.7330 & 16.4080 & 14.7000 \\
\hline Profitability & 0.0448 & 0.0690 & 0.0964 & 0.0658 & 0.1144 & 0.0804 & 0.1014 & 0.0634 & 0.1061 & 0.0937 & 0.0574 & 0.1018 & 0.0753 & 0.0773 & 0.0700 & 0.0878 \\
\hline Leverage & 0.1369 & 0.2060 & 0.0249 & 0.1336 & 0.0839 & 0.2219 & 0.1031 & 0.1507 & 0.1288 & 0.0959 & 0.2821 & 0.1009 & 0.14967 & 0.1400 & 0.2316 & 0.1723 \\
\hline Tone & -0.0009 & -0.0003 & 0.0036 & 0.0007 & -0.0047 & 0.0028 & 0.0052 & 0.0050 & 0.0037 & 0.0022 & -0.0096 & -0.0034 & -0.0002 & -0.0032 & -0.0017 & 0.0019 \\
\hline Readability & -0.3717 & -0.4833 & -0.4983 & -0.6884 & -0.2848 & -0.4667 & -0.4616 & -0.4816 & -0.5451 & -0.4749 & -0.5078 & -0.4378 & -0.6477 & -0.5376 & -0.3297 & -0.3600 \\
\hline$A 4 I R$ & 59.8380 & 67.0759 & 68.5628 & 75.9507 & 65.1073 & 85.3135 & 85.4924 & 82.4005 & 79.8573 & 58.2720 & 67.9009 & 52.9281 & 84.6431 & 81.8209 & 86.9336 & 74.1934 \\
\hline DJSI & - & 0.0686 & 0.2305 & 0.3661 & 0.2059 & 0.4412 & 0.1638 & 0.2309 & 0.2486 & 0.0725 & 0.2466 & - & 0.3830 & 0.3108 & 0.3200 & 0.1063 \\
\hline factor_csr & 0.8791 & 0.2731 & 1.0379 & 0.6454 & 1.6850 & -1.5144 & 1.2765 & -0.4643 & 0.0795 & 0.4121 & -1.5203 & - & 1.0471 & 1.1759 & -1.5845 & 1.1882 \\
\hline factor_empl & 0.4823 & -0.1088 & 0.2837 & 1.2596 & 0.3543 & 1.3889 & 0.2158 & 1.2945 & -2.0264 & -0.7710 & 0.9334 & - & 0.7217 & 1.2254 & 1.6069 & 1.2678 \\
\hline factor_leg & 0.8744 & 0.6086 & 1.0645 & 0.8675 & 1.2710 & 0.6283 & 1.2012 & 0.8016 & 0.6101 & 0.8951 & 0.0553 & - & 0.8611 & 1.2026 & 0.7008 & 1.3174 \\
\hline factor_enf & 0.2815 & -0.1318 & 1.3825 & 0.9470 & 0.2996 & 0.2873 & 0.1703 & -0.1074 & -0.2734 & -0.4452 & -0.9012 & - & -0.4393 & 0.6825 & 0.4359 & 0.6118 \\
\hline Observation & 61 & 102 & 351 & 267 & 136 & 204 & 121 & 598 & 1,226 & 71 & 148 & 35 & 191 & 76 & 25 & 349 \\
\hline
\end{tabular}


APPENDIX IV Institutional Variables per Country

\begin{tabular}{|c|c|c|c|c|c|c|c|c|c|c|c|c|c|c|c|c|c|c|c|c|}
\hline \multirow[b]{2}{*}{ Country } & \multicolumn{11}{|c|}{ factor_leg } & \multicolumn{4}{|c|}{ factor_csr } & \multicolumn{2}{|c|}{ factor_enf } & \multicolumn{3}{|c|}{ factor_empl } \\
\hline & $\begin{array}{c}\text { SoSe } \\
\text { c_La } \\
\text { w }\end{array}$ & HRI & $\begin{array}{l}\text { Rule } \\
\text { Law }\end{array}$ & $\begin{array}{l}\text { Voic } \\
\text { e_Ac } \\
\text { ct }\end{array}$ & $\begin{array}{c}\text { Gov_ } \\
\text { Eff }\end{array}$ & $\begin{array}{l}\mathrm{Reg}_{-} \\
\text {Qual }\end{array}$ & $\begin{array}{l}\text { Brib } \\
\text { Corr }\end{array}$ & EPI & $\begin{array}{c}\text { Jour }_{-} \\
\text {Free }\end{array}$ & $\begin{array}{l}\text { Corr- } \\
\text { Contr }\end{array}$ & $\begin{array}{l}\text { Law } \\
\& O r \\
\text { der }\end{array}$ & $\begin{array}{c}\text { Sust_ } \\
\text { Dev }\end{array}$ & $\begin{array}{l}\text { Eth- } \\
\text { Pract }\end{array}$ & $\begin{array}{l}\text { Soc } \\
\text { Resp }\end{array}$ & $\begin{array}{l}\text { Env } \\
\text { Laws }\end{array}$ & $\begin{array}{l}\text { Gov }_{-} \\
\text {Stab }\end{array}$ & PEI & $\begin{array}{l}\text { Emp } \\
\text { Law }\end{array}$ & $\begin{array}{l}\text { Coll_ } \\
\text { Law }\end{array}$ & ASD \\
\hline$A T$ & 0.7 & 95.0 & 1.8 & 1.4 & 1.6 & 1.5 & 6.2 & 84.8 & 3.8 & 1.6 & 6.0 & 7.3 & 7.4 & 6.8 & 6.3 & 7.2 & 1.0 & 0.5 & 0.4 & 0.2 \\
\hline$B E$ & 0.6 & 96.0 & 1.4 & 1.4 & 1.5 & 1.3 & 6.3 & 78.9 & 6.4 & 1.6 & 5.0 & 6.4 & 7.2 & 6.0 & 5.9 & 7.3 & 0.5 & 0.5 & 0.4 & 0.5 \\
\hline $\mathrm{CH}$ & 0.9 & 98.0 & 1.9 & 1.6 & 2.0 & 1.8 & 9.1 & 88.4 & 2.9 & 2.3 & 6.0 & 7.9 & 8.2 & 7.6 & 7.4 & 7.0 & 0.8 & 0.6 & 0.4 & 0.5 \\
\hline GER & 0.8 & 99.0 & 2.0 & 1.5 & 2.1 & 1.8 & 8.6 & 90.6 & 1.2 & 2.2 & 6.0 & 7.3 & 8.1 & 6.6 & 7.5 & 7.3 & 0.0 & 0.7 & 0.3 & 0.5 \\
\hline$D K$ & 0.8 & 94.0 & 1.5 & 1.2 & 1.4 & 1.2 & 6.2 & 86.7 & 15.5 & 1.4 & 5.0 & 5.8 & 6.8 & 5.4 & 6.4 & 6.7 & 0.5 & 0.7 & 0.7 & 0.4 \\
\hline$E S$ & 0.7 & 98.0 & 1.7 & 1.4 & 1.6 & 1.6 & 7.2 & 83.5 & 5.9 & 1.8 & 5.0 & 7.3 & 7.7 & 6.2 & 6.5 & 8.1 & 1.0 & 0.7 & 0.6 & 0.3 \\
\hline$F I$ & 0.7 & 94.0 & 1.7 & 1.3 & 1.5 & 1.7 & 7.1 & 87.6 & 11.5 & 1.6 & 6.0 & 6.2 & 7.4 & 6.1 & 7.0 & 6.7 & 0.0 & 0.3 & 0.5 & 0.8 \\
\hline$F R$ & 0.8 & 90.0 & 0.4 & 1.0 & 0.4 & 0.8 & 2.2 & 83.4 & 20.9 & 0.1 & 4.0 & 5.1 & 5.0 & 4.7 & 5.5 & 6.9 & 0.0 & 0.6 & 0.6 & 0.4 \\
\hline$G B$ & 0.6 & 98.0 & 1.9 & 1.5 & 1.8 & 1.8 & 7.8 & 80.9 & 4.5 & 2.1 & 6.0 & 6.9 & 7.8 & 6.4 & 6.4 & 7.0 & 0.0 & 0.7 & 0.5 & 0.2 \\
\hline$I E$ & 0.8 & 97.0 & 2.0 & 1.6 & 1.9 & 1.6 & 7.1 & 87.3 & 4.3 & 2.2 & 6.0 & 7.3 & 8.0 & 7.2 & 7.7 & 7.4 & 1.0 & 0.7 & 0.6 & 0.4 \\
\hline$I T$ & 0.7 & 92.0 & 1.1 & 1.1 & 1.1 & 0.8 & 3.8 & 87.8 & 11.1 & 1.0 & 5.0 & 5.3 & 5.2 & 4.3 & 6.4 & 6.9 & 1.0 & 0.8 & 0.6 & 0.4 \\
\hline$N L$ & 0.8 & 87.0 & 1.1 & 1.1 & 1.1 & 1.0 & 3.7 & 87.6 & 14.6 & 0.9 & 5.0 & 5.4 & 5.3 & 4.6 & 5.8 & 6.8 & 1.0 & 0.7 & 0.6 & 0.4 \\
\hline$N O$ & 0.8 & 98.0 & 2.0 & 1.6 & 1.9 & 1.8 & 7.9 & 89.2 & 3.6 & 2.2 & 6.0 & 7.5 & 8.1 & 7.0 & 7.7 & 6.9 & 1.0 & 0.7 & 0.5 & 0.3 \\
\hline$P T$ & 0.8 & 96.0 & 1.8 & 1.6 & 2.0 & 1.7 & 8.1 & 86.3 & 4.2 & 2.1 & 5.0 & 7.1 & 8.0 & 6.5 & 7.7 & 8.8 & 0.8 & 0.5 & 0.4 & 0.3 \\
\hline$S E$ & 0.7 & 93.0 & 1.7 & 1.3 & 1.6 & 1.7 & 6.9 & 70.9 & 10.9 & 1.7 & 5.2 & 5.5 & 7.3 & 5.6 & 6.1 & 7.4 & 0.0 & 0.3 & 0.2 & 1.0 \\
\hline
\end{tabular}




\begin{tabular}{|c|c|c|c|c|c|c|c|c|}
\hline & & & & & & 275 & . & \\
\hline Size & 154162 & 15776 & 70884 & 143123 & 154356 & 165642 & 104884 & 3285 \\
\hline & & & & & & 10.5042 & & (ד) \\
\hline Profitability & 0.0875 & 0.1482 & -0.8007 & 0.0344 & 0.0712 & 0.1151 & 3.1610 & 3,285 \\
\hline Leverage & 0.1391 & 0.2148 & -0.9299 & 0.0088 & 0.1474 & 0.2769 & 1.1009 & 3,285 \\
\hline discl_tone & 0.0023 & 0.0104 & -0.0232 & -0.0039 & 0.0014 & 0.0070 & 0.0694 & 3,303 \\
\hline discl_readability & -0.5067 & 0.2734 & -1.0000 & -0.7333 & -0.5033 & -0.2867 & -0.0100 & 3,303 \\
\hline$a 4 i r$ & 78.8797 & 21.8444 & 3.1400 & 75.5600 & 88.0800 & 92.8300 & 97.4500 & 3,165 \\
\hline DJSI & 0.2484 & 0.4322 & 0.0000 & 0.0000 & 0.0000 & 0.0000 & 1.0000 & 3,297 \\
\hline factor_csr & 0.2343 & 0.8296 & -1.5845 & 0.0795 & 0.0795 & 1.0379 & 1.6850 & 3,303 \\
\hline factor_empl & -0.0779 & 1.4362 & -2.0264 & -2.0264 & 0.3543 & 1.2678 & 1.6069 & 3,303 \\
\hline factor_leg & 0.8099 & 0.2845 & 0.0553 & 0.6101 & 0.8016 & 1.0645 & 1.3174 & 3,303 \\
\hline factor enf & 0.1019 & 0.5686 & -0.9012 & -0.2734 & -0.1074 & 0.4359 & 1.3825 & 3,303 \\
\hline
\end{tabular}

APPENDIX VI Descriptives for variables entering further analyses 


\section{References}

Aguilera, R. V., \& Jackson, G. (2003). The Cross-National Diversity of Corporate Governance: Dimensions and Determinants. Academy of management review, 28(3), 447-465.

Al-Tuwaijri, S. A., Christensen, T. E., \& Hughes, K. E. (2004). The Relations among Environmental Disclosure, Environmental Performance, and Economic Performance: A Simultaneous Equations Approach. Accounting, Organizations and Society, 29(5-6), 447-471.

Allee, K. D., \& DeAngelis, M. D. (2015). The Structure of Voluntary Disclosure Narratives: Evidence from Tone Dispersion. Journal of Accounting Research, 53(2), 241-274.

Amernic, J. (1992). A Case Study in Corporate Financial Reporting: Mayssey-Ferguson's Visible Accounting Decisions 1970-1987. Critical Perspectives on Accounting, 3(1), $1-43$.

Anderson, R., \& Epstein, M. (1995). The Usefulness on Annual Reports. Australian Accountant, 65(3), 25.

Ball, R., Kothari, S., \& Robin, A. (2000). The Effect of International Institutional Factors on Properties of Accounting Earnings. Journal of Accounting and Economics, 29(1), 151.

Ball, R., Robin, A., \& Wu, J. S. (2003). Incentives Versus Standards: Properties of Accounting Income in Four East Asian Countries. Journal of Accounting and Economics, 36(1-3), 235-270.

Barth, M. E., Cahan, S. F., Chen, L., \& Venter, E. R. (2017). The Economic Consequences Associated with Integrated Report Quality: Capital Market and Real Effects. Accounting, Organizations and Society, 62, 43-64.

Barth, M. E., Landsman, W. R., Lang, M., \& Williams, C. (2012). Are Ifrs-Based and Us Gaap-Based Accounting Amounts Comparable? Journal of Accounting and Economics, 54(1), 68-93.

Bernardi, C., \& Stark, A. W. (2018). Environmental, Social and Governance Disclosure, Integrated Reporting, and the Accuracy of Analyst Forecasts. The British Accounting Review, 50(1), 16-31. 
Biddle, G., Hilary, G., \& Verdi, R. (2009). How Does Financial Reporting Quality Relate to Investment Efficiency? Journal of Accounting and Economics, 48(2-3), 112-131.

Blacconiere, W. G., \& Patten, D. M. (1994). Environmental Disclosure, Regulatory Costs, and Changes in Firm Value. Journal of Accounting and Economics, 18(3), 357-377.

Botero, J., Djankov, S., La Porta, R., Lopez-De-Silanes, F., \& Shleifer, A. (2004). The Regulation of Labor. Quarterly Journal of Economics, 119(4), 1339-1382.

Burgstahler, D. C., Hail, L., \& Leuz, C. (2006). The Importance of Reporting Incentives: Earnings Management in European Private and Public Firms. The Accounting Review, 81(5), 983-1016.

Bushman, R. M., \& Piotroski, J. D. (2006). Financial Reporting Incentives for Conservative Accounting: The Influence of Legal and Political Institutions. Journal of Accounting and Economics, 42(1-2), 107-148.

Cahan, S. F., De Villiers, C., Jeter, D. C., Naiker, V., \& Van Staden, C. J. (2016). Are Csr Disclosures Value Relevant? Cross-Country Evidence. European Accounting Review, 25(3), 579-611.

Campbell, D., \& Slack, R. (2008). Corporate "Philanthropy Strategy" and "Strategic Philanthropy". Some Insights from Voluntary Disclosures in Annual Reports. Business \& Society, 47(2), 187-212.

Cannon, J. N., Ling, Z., Wang, Q., \& Watanabe, O. (2017). 10-K Disclosure of Corporate Social Responsibility and Firms' Competitive Advantages. Unpublished manuscript, School of Accountancy, Iowa State University, Ames, IA.

Chen, S., \& Bouvain, P. (2009). Is Corporate Responsibility Converging? A Comparison of Corporate Responsibility Reporting in the USA, Uk, Australia, and Germany. Journal of Business Ethics, 87, 299-317.

Cho, C. H., Roberts, R. W., \& Patten, D. M. (2010). The Language of Us Corporate Environmental Disclosure. Accounting, Organizations and Society, 35(4), 431-443.

Clarkson, P. M., Fang, X., Li, Y., \& Richardson, G. D. (2013). The Relevance of Environmental Disclosures: Are Such Disclosures Incrementally Informative? Journal of Accounting and Public Policy, 32(5), 410-431.

Core, J. E., Hail, L., \& Verdi, R. S. (2015). Mandatory Disclosure Quality, inside Ownership, and Cost of Capital. European Accounting Review, 24(1), 1-29. 
Cormier, D., Ledoux, M.-J., \& Magnan, M. (2011). The Informational Contribution of Social and Environmental Disclosures for Investors. Management Decision, 49(8), 12761304.

Cormier, D., Magnan, M., \& van Velthoven, B. (2005). Environmental Disclosure Quality in Large German Companies: Economic Incentives, Public Pressures or Institutional Conditions? European Accounting Review, 14(1), 3-39.

Crossno, P. J., Wilson, A. T., Shead, T. M., \& Dunlavy, D. M. (2011, November). Topicview: Visually Comparing Topic Models of Text Collections. In 2011 23rd IEEE International Conference on Tools with Artificial Intelligence ICTAI 2011 (pp. 936943). Boca Raton, FL.

Daske, H., Hail, L., Leuz, C., \& Verdi, R. (2008). Mandatory Ifrs Reporting around the World: Early Evidence on the Economic Consequences. Journal of Accounting Research, 46(5), 1085-1142.

Daske, H., Hail, L., Leuz, C., \& Verdi, R. (2013). Adopting a Label: Heterogeneity in the Economic Consequences around Ias/Ifrs Adoptions. Journal of Accounting Research, $51(3), 495-547$.

De Franco, G., Hope, O., Vyas, D., \& Zhou, Y. (2015). Analyst Report Readability. Contemporary Accounting Research, 32(1), 76-104.

De Villiers, C., \& Marques, A. (2016). Corporate Social Responsibility, Country-Level Predispositions, and the Consequences of Choosing a Level of Disclosure. Accounting and Business Research, 46(2), 167-195.

Dhaliwal, D. S., Li, O. Z., Tsang, A., \& Yang, Y. G. (2011). Voluntary Nonfinancial Disclosure and the Cost of Equity Capital: The Initiation of Corporate Social Responsibility Reporting. The Accounting Review, 86(1), 59-100.

Dhaliwal, D. S., Li, O. Z., Tsang, A., \& Yang, Y. G. (2014). Corporate Social Responsibility Disclosure and the Cost of Equity Capital: The Roles of Stakeholder Orientation and Financial Transparency. Journal of Accounting and Public Policy, 33(4), 328-355.

Dhaliwal, D. S., Radhakrishnan, S., Tsang, A., \& Yang, Y. G. (2012). Nonfinancial Disclosure and Analyst Forecast Accuracy: International Evidence on Corporate Social Responsibility Disclosure. The Accounting Review, 87(3), 723-759. 
Dixon-Fowler, H., Slater, D., Johnson, J., Ellstrand, A., \& Romi, A. (2013). Beyond 'Does It Pay to Be Green?' A Meta-Analysis of Moderators of the Cep-Cfp Relationship. Journal of Business Ethics, 112(2), 353-366.

Djankov, S., La Porta, R., Lopez-de-Silanes, F., \& Shleifer, A. (2008). The Law and Economics of Self-Dealing. Journal of Financial Economics, 88(3), 430-465.

Dorfleitner, G., Halbritter, G., \& Nguyen, M. (2015). Measuring the Level and Risk of Corporate Responsibility - an Empirical Comparison of Different Esg Rating Approaches. Journal of Asset Management, 16(7), 450-466.

Ernstberger, J., Krotter, S., \& Stadler, C. (2008). Analysts' Forecast Accuracy in Germany: The Effect of Different Accounting Principles and Changes of Accounting Principles. Business Research, 1(1), 26-53.

Communication from the Commission: Guidelines on Non-Financial Reporting (Methodology for Reporting Non-Financial Information), C 215/2 C.F.R. (2017).

Directive 2014/95/Eu of the European Parliament and of the Council of 22 October 2014 Amending Directive 2013/34/Eu as Regards Disclosure of Non-Financial and Diversity Information by Certain Large Undertakings and Groups, L 330/1 C.F.R. (2014).

Fama, E. F., \& French, K. R. (2017). Industry Classification. Retrieved from http://mba.tuck.dartmouth.edu/pages/faculty/ken.french/data library.html

Fiechter, P., Hitz, J.-M., \& Lehmann, N. (2017). Real Effects of Disclosure Regulation: Evidence from the European Union's Csr Directive. Unpublished manuscript, Institute of Financial Analysis, University of Neuchatel, Neuchatel, Switzerland.

Fifka, M. S. (2013a). Corporate Citizenship in Germany and the United States - Differing Perceptions and Practices in Transatlantic Comparison. Business Ethics: A European Review, 22(4), 341-356.

Fifka, M. S. (2013b). Corporate Responsibility Reporting and Its Determinants in Comparative Perspective - a Review of the Empirical Literature and a Meta-Analysis. Business Strategy and the Environment, 22(1), 1-35.

Fombrun, C., \& Shanley, M. (1990). What's in a Name? Reputation Building and Corporate Strategy. Academy of Management journal, 33(2), 233. 
Francis, J., Nanda, D., \& Olsson, P. E. R. (2008). Voluntary Disclosure, Earnings Quality, and Cost of Capital. Journal of Accounting Research, 46(1), 53-99.

Gaio, C. (2010). The Relative Importance of Firm and Country Characteristics for Earnings Quality around the World. European Accounting Review, 19(4), 693-738.

Gao, F., Dong, Y., Ni, C., \& Fu, R. (2015). Determinants and Economic Consequences of Non-Financial Disclosure Quality. European Accounting Review, 25(2), 287-317.

Gray, R., Kouhy, R., \& Lavers, S. (1995). Corporate Social and Environmental Reporting: A Review of the Literature and a Longitudinal Study of Uk Disclosure. Accounting, Auditing \& Accountability Journal, 8(2), 47-77.

Grewal, J., Riedl, E. J., \& Serafeim, G. (2017). Market Reaction to Mandatory Nonfinancial Disclosure. Unpublished manuscript, Harvard Business School, Boston, MA.

Hail, L., \& Leuz, C. (2006). International Differences in the Cost of Equity Capital: Do Legal Institutions and Securities Regulation Matter? Journal of Accounting Research, 44(3), 485-531.

Hair, J. F., Black, W. C., Babin, B. J., \& Anderson, R. E. (2010). Multivariate Data Analysis: A Global Perspective. (7th ed.). Upper Saddle River, NJ: Pearson.

Hall, P. A., \& Soskice, D. (2001). Varieties of Capitalisms: The Instituational Foundations of Comparative Advantage. Oxford, NY: Oxford University Press.

Healy, P. M., \& Palepu, K. G. (2001). Information Asymmetry, Corporate Disclosure, and the Capital Markets: A Review of the Empirical Disclosure Literature. Journal of Accounting and Economics, 31(1-3), 405-440.

Henry, E., \& Leone, A. J. (2016). Measuring Qualitative Information in Capital Markets Research: Comparison of Alternative Methodologies to Measure Disclosure Tone. The Accounting Review, 91(1), 153-178.

Hoberg, G., \& Maksimovic, V. (2015). Redefining Financial Constraints: A Text-Based Analysis. Review of Financial Studies, 28(5), 1312-1352.

Hofstede, G. (1983). The Cultural Relativity of Organizational Practices and Theories. Journal of International Business Studies, 14(2), 75-89.

Hope, O.-K. (2003). Disclosure Practices, Enforcement of Accounting Standards, and Analysts' Forecast Accuracy: An International Study. Journal of Accounting Research, 41(2), 235-272. 
Huang, A., Lehavy, R., Zang, A., \& Zheng, R. (2017). Analyst Information Discovery and Interpretation Roles: A Topic Modeling Approach. Management Science, 64(6), 28332855.

Huang, A., Zang, A., \& Rong, Z. (2014). Evidence on the Information Content of Text in Analyst Reports. The Accounting Review, 89(6), 2151-2180.

Huang, X., Teoh, S. H., \& Zhang, Y. (2014). Tone Management. The Accounting Review, 89(3), 1083-1113.

Humana, C. (1992). World Human Rights Guide. Oxford, NY: Oxford University Press.

Hummel, K., Mittelbach-Hoermanseder, S., Cho, C., \& Matten, D. (2017). The Implicit Versus Explicit Corporate Social Responsibility Disclosure: A Textual Analysis. Unpublished manuscript, Department of Business Administration, University of Zurich, Zurich, Switzerland.

Hummel, K., \& Schlick, C. (2016). The Relationship between Sustainability Performance and Sustainability Disclosure - Reconciling Voluntary Disclosure Theory and Legitimacy Theory. Journal of Accounting and Public Policy, 35(5), 455-476.

Ioannou, I., \& Serafeim, G. (2012). What Drives Corporate Social Performance? The Role of National-Level Institutions. Journal of International Business Studies, 43(9), 834-864.

Ioannou, I., \& Serafeim, G. (2014). The Consequences of Mandatory Corporate Sustainability Reporting: Evidence from Four Countries (Working paper). Harvard Business School.

Ioannou, I., \& Serafeim, G. (2017). The Consequences of Mandatory Corporate Sustainability Reporting (Working paper). Harvard Business School.

Isidro, H., \& Marques, A. (2015). The Role of Institutional and Economic Factors in the Strategic Use of Non-Gaap Disclosures to Beat Earnings Benchmarks. European Accounting Review, 24(1), 95-128.

Jeanjean, T., \& Stolowy, H. (2008). Do Accounting Standards Matter? An Exploratory Analysis of Earnings Management before and after Ifrs Adoption. Journal of Accounting and Public Policy, 27(6), 480-494.

Kolk, A., \& Perego, P. (2010). Determinants of the Adoption of Sustainability Assurance Statements: An International Investigation. Business Strategy and the Environment, 19(3), 182-198. 
Kraay, A., Kaufmann, D., \& Mastruzzi, M. (2010). The Worldwide Governance Indicators: Methodology and Analytical Issues. Policy Research working paper, Development Research Group, The World Bank, Washington, D.C.

Lang, M., \& Stice-Lawrence, L. (2015). Textual Analysis and International Financial Reporting: Large Sample Evidence. Journal of Accounting and Economics, 60(2-3), 110.

Lehavy, R., Li, F., \& Merkley, K. (2011). The Effect of Annual Report Readability on Analyst Following and the Properties of Their Earnings Forecasts. The Accounting Review, 86(3), 1087-1115.

Leuz, C., Nanda, D., \& Wysocki, P. D. (2003). Earnings Management and Investor Protection: An International Comparison. Journal of Financial Economics, 69(3), 505527.

Leuz, C., \& Verrecchia, R. E. (2000). The Economic Consequences of Increased Disclosure. Journal of Accounting Research, 38(3), 91-124.

Leuz, C., \& Wysocki, P. (2016). The Economics of Disclosure and Financial Reporting Regulation: Evidence and Suggestions for Future Research. Journal of Accounting Research, 54(2), 525-622.

Lev, B., Petrovits, C., \& Radhakrishnan, S. (2010). Is Doing Good Good for You? How Corporate Charitable Contributions Enhance Revenue Growth. Strategic Management Journal, 31(2), 182-200.

Li, F. (2008). Annual Report Readability, Current Earnings, and Earnings Persistence. Journal of Accounting and Economics, 45(2), 221-247.

Lo, K., Ramos, F., \& Rogo, R. (2017). Earnings Management and Annual Report Readability. Journal of Accounting and Economics, 63(1), 1-25.

Loughran, T., \& McDonald, B. (2011). When Is a Liability Not a Liability? Textual Analysis, Dictionaries, and 10-Ks. Journal of Finance, 66(1), 35-65.

Loughran, T., \& McDonald, B. (2016). Textual Analysis in Accounting and Finance: A Survey. Journal of Accounting Research, 54(4), 1187-1230.

Loughran, T., McDonald, B., \& Yun, H. (2009). A Wolf in Sheep's Clothing: The Use of Ethics-Related Terms in 10-K-Reports. Journal of Business Ethics, 89(1), 39-49. 
Lu, L. Y., Shailer, G., \& Yu, Y. (2016). Corporate Social Responsibility Disclosure and the Value of Cash Holdings. European Accounting Review, 26(4), 729-753.

Lys, T., Naughton, J. P., \& Wang, C. (2015). Signaling through Corporate Accountability Reporting. Journal of Accounting and Economics, 60(1), 56-72.

Maignan, I., \& Ralston, D. A. (2002). Corporate Social Responsibility in Europe and the U.S.: Insights from Businesses' Self-Presentations. Journal of International Business Studies, 33(3), 497-514.

Matsumura, E. M., Prakash, R., \& Vera-Muñoz, S. C. (2014). Firm-Value Effects of Carbon Emissions and Carbon Disclosures. The Accounting Review, 89(2), 695-724.

Matten, D., \& Moon, J. (2008). "Implicit" and "Explicit" Csr: A Conceptual Framework for a Comparative Understanding of Corporate Social Responsibility. Academy of management review, 33(2), 404-424.

Maurice, M., \& Sorge, A. (Ed.). (2000). Embedding Organizations: Societal Analysis of Actors, Organizations and Socio-Economic Context. Amsterdam, NL: John Benjamins B.V.

Maurice, M., Sorge, A., \& Warner, M. (1980). Societal Differences in Organizing Manufacturing Units: A Comparison of France, West Germany and Great Britain. Organization Studies, 1(1), 59-86.

Melloni, G., Caglio, A., \& Perego, P. (2017). Saying More with Less? Disclosure Conciseness, Completeness and Balance in Integrated Reports. Journal of Accounting and Public Policy, 36(3), 220-238.

Miller, B. P. (2010). The Effects of Reporting Complexity on Small and Large Investor Trading. The Accounting Review, 85(6), 2107-2143.

Muslu, V., Mutlu, S., Radhakrishnan, S., \& Tsang, A. (2016). Corporate Social Responsibility Report Narratives and Analyst Forecast Accuracy. Journal of Business Ethics, 154(4), 1119-1142.

Nazari, J. A., Hrazdil, K., \& Mahmoudian, F. (2017). Assessing Social and Environmental Performance through Narrative Complexity in Csr Reports. Journal of Contemporary Accounting \& Economics, 13(2), 166-178. 
O’Donovan, G. (2002). Environmental Disclosures in the Annual Report: Extending the Applicability and Predictive Power of Legitimacy Theory. Accounting, Auditing \& Accountability Journal, 15(3), 344-371.

Ohlson, J. A. (1995). Earnings, Book Values, and Dividends in Equity Valuation. Contemporary Accounting Research, 11(2), 661-687.

Orij, R. (2010). Corporate Social Disclosures in the Context of National Cultures and Stakeholder Theory. Accounting, Auditing \& Accountability Journal, 23(7), 868-889.

Pagano, M., \& Volpin, P. F. (2005). The Political Economy of Corporate Governance. American Economic Review, 95(4), 1005-1030.

Pencle, N., \& Mălăescu, I. (2016). What's in the Words? Development and Validation of a Multidimensional Dictionary for Csr and Application Using Prospectuses. Journal of Emerging Technologies in Accounting, 13(2), 109-127.

Peng, C. W., \& Yang, M. L. (2014). The Effect of Corporate Social Performance on Financial Performance: The Moderating Effect of Ownership Concentration. Journal of Business Ethics, 123(1), 171-182.

Plumlee, M., Brown, D., Hayes, R. M., \& Marshall, R. S. (2015). Voluntary Environmental Disclosure Quality and Firm Value: Further Evidence. Journal of Accounting and Public Policy, 34(4), 336-361.

Porter, M. F. (1980). An Algorithm for Suffix Stripping. Program, 14(3), 130-137.

Richardson, A. J., \& Welker, M. (2001). Social Disclosure, Financial Disclosure and the Cost of Equity Capital. Accounting, Organizations \& Society, 26(7-8), 597-616.

Salancik, G. R., \& Meindl, J. R. (1984). Corporate Attributions as Strategic Illusions of Management Control. Administrative Science Quarterly, 29(2), 238-254.

Simnett, R., Vanstraelen, A., \& Chua, W. F. (2009). Assurance on Sustainability Reports: An International Comparison. The Accounting Review, 84(3), 937-967.

Ullmann, A. A. (1985). Data in Search of a Theory: A Critical Examination of the Relationships among Social Performance, Social Disclosure, and Economic Performance of U.S. Firms. Academy of management review, 10(3), 540-557.

Van der Laan Smith, J., Adhikari, A., \& Tondkar, R. H. (2005). Exploring Differences in Social Disclosures Internationally: A Stakeholder Perspective. Journal of Accounting and Public Policy, 24(2), 123-151. 
Vance, S. C. (1975). Are Socially Responsible Corporations Good Investment Risks. Management review, 64(8), 19-24.

Verrecchia, R. E. (1983). Discretionary Disclosure. Journal of Accounting and Economics, 5(3), 179-194.

Wang, J. W., \& Yu, W. W. (2015). The Information Content of Stock Prices, Legal Environments, and Accounting Standards: International Evidence. European Accounting Review, 24(3), 471-493. 


\section{Tables}

Table 1 Sample Selection and Distribution

\begin{tabular}{|c|c|c|}
\hline \multicolumn{2}{|c|}{ Panel A: Sample selection } & tol \\
\hline \multicolumn{2}{|c|}{ Initial population of firm-year observations for 600 firms $(2008-2016)$} & 5,400 \\
\hline \multicolumn{2}{|c|}{ Less: observations for which the annual report is not available } & -377 \\
\hline \multicolumn{2}{|c|}{$=$ firm-year observations with available annual reports } & 5,023 \\
\hline \multicolumn{2}{|c|}{ Less: observations that cannot be processed in textual analysis } & -850 \\
\hline \multicolumn{2}{|c|}{$=$ firm-year observations with processable annual reports } & 4,173 \\
\hline \multicolumn{2}{|c|}{ Less: observations with missing main variables } & -212 \\
\hline \multicolumn{2}{|c|}{ Total sample } & 3,961 \\
\hline \multicolumn{3}{|c|}{ Panel B: Sample distribution by industry group } \\
\hline \multicolumn{2}{|c|}{ 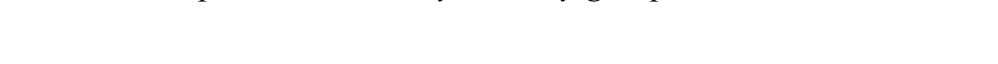 } & Freq. \\
\hline 1 & Consumer Non-durables & 291 \\
\hline 2 & Consumer Durables & 130 \\
\hline 3 & Manufacturing & 515 \\
\hline 4 & Energy & 92 \\
\hline 5 & Chemicals & 209 \\
\hline 6 & Business equipment & 260 \\
\hline 7 & Communication & 227 \\
\hline 8 & Utilities & 164 \\
\hline 9 & Wholesale & 306 \\
\hline 10 & Healthcare & 265 \\
\hline 11 & Finance & 824 \\
\hline 12 & Other & 678 \\
\hline \multicolumn{2}{|c|}{ Total sample } & 3,961 \\
\hline \multicolumn{3}{|c|}{ Panel C: Sample distribution by countries } \\
\hline \multicolumn{2}{|c|}{ 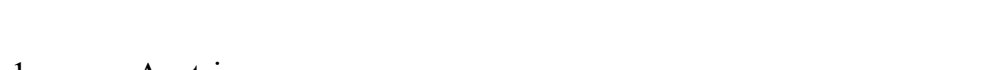 } & Freq. \\
\hline 1 & Austria & 61 \\
\hline 2 & Belgium & 102 \\
\hline 3 & Switzerland & 351 \\
\hline 4 & Germany & 267 \\
\hline 5 & Denmark & 136 \\
\hline 6 & Spain & 204 \\
\hline 7 & Finland & 121 \\
\hline 8 & France & 598 \\
\hline 9 & United Kingdom & 1,226 \\
\hline 10 & Ireland & 71 \\
\hline 11 & Italy & 148 \\
\hline 12 & Luxembourg & 35 \\
\hline 13 & Netherlands & 191 \\
\hline 14 & Norway & 76 \\
\hline 15 & Portugal & 25 \\
\hline 16 & Sweden & 349 \\
\hline \multicolumn{2}{|c|}{ Total sample } & 3,961 \\
\hline
\end{tabular}


Table 2 Overview of Textual Variables

\begin{tabular}{|c|c|c|c|}
\hline \multicolumn{4}{|c|}{ Panel A: Top-20 Words } \\
\hline $\mathrm{T}_{\mathrm{i}}$ & Top 20 words & $\begin{array}{l}\text { Total number } \\
\text { of words }\end{array}$ & $\begin{array}{l}\text { Number of } \\
\text { unique words }\end{array}$ \\
\hline$T_{E N V}$ & $\begin{array}{l}\text { 'ecology' (989), 'development' (418), 'sustainable' (406), 'energy' } \\
(363), \text { 'ministry' (299), 'management' (176), 'environmental' (164), } \\
\text { 'director' (123), 'sustainability' (122), 'biodiversity' (120), 'project' } \\
\text { (113), 'company’ (105), 'report' (101), 'use' (99), 'economy’ (98), } \\
\text { 'environment' (91), 'climate' (86), 'material' (80), 'transport' (76), } \\
\text { 'building' (75) }\end{array}$ & 18,280 & 3,343 \\
\hline$T_{S O C}$ & 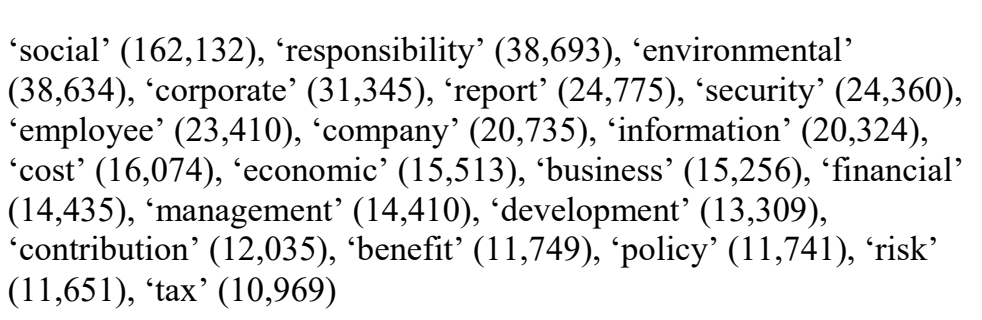 & $2,565,511$ & 42,115 \\
\hline$T_{E M P}$ & $\begin{array}{l}\text { 'employee' (865,083), 'share' }(224,953) \text {, 'benefit' }(136,486), \text { 'plan' } \\
(133,910) \text {, 'company' }(128,974) \text {, 'number' }(88,554) \text {, 'director' } \\
(59,063) \text {, 'management' }(57,249) \text {, 'option' }(57,222) \text {, 'board' } \\
(52,515) \text {, 'financial' }(52,502) \text {, 'business' }(52,492) \text {, 'pension' } \\
(51,067) \text {, 'service' }(48,306), \text { 'cost' }(47,934) \text {, 'report' }(47,747), \\
\text { 'scheme' }(46,254), \text { 'executive' }(45,483), \text { 'performance' }(45,046), \\
\text { 'based' }(43,771)\end{array}$ & $11,125,751$ & 76,627 \\
\hline$T_{H R}$ & 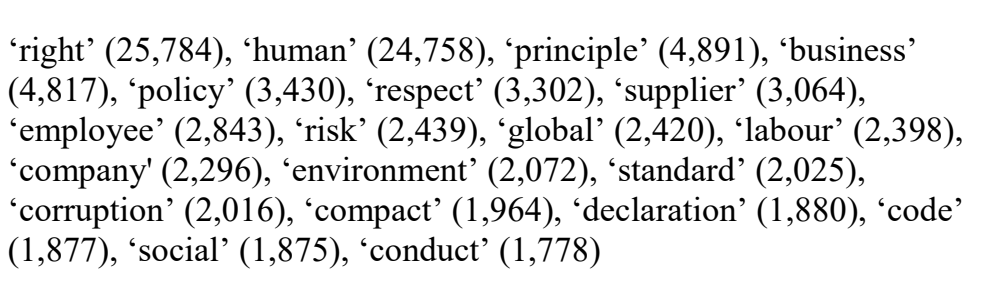 & 338,393 & 8,621 \\
\hline$T_{C O R R}$ & 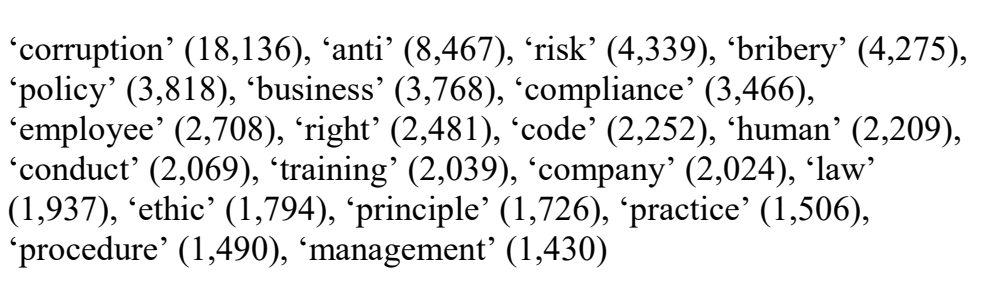 & 278,992 & 8,134 \\
\hline$T_{B R I B}$ & 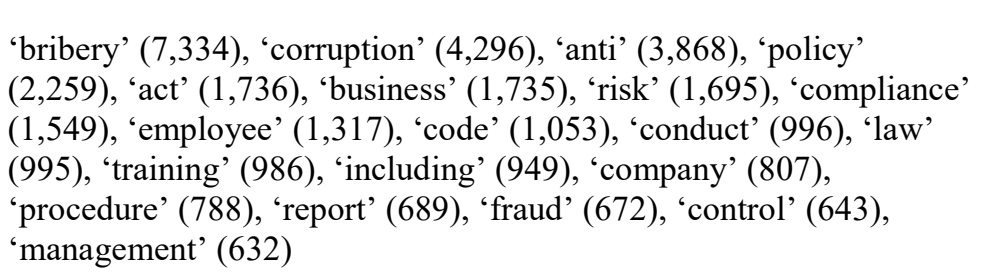 & 118,180 & 4,996 \\
\hline
\end{tabular}




\begin{tabular}{|c|c|c|}
\hline \multicolumn{3}{|c|}{ Panel B: Word Window Examples } \\
\hline & Twenty-word window & Corresponding CSR disclosure \\
\hline$T_{E N V}$ & $\begin{array}{l}\mathrm{T}_{\mathrm{ENV}} \text { : 'system', 'energy', } \\
\text { 'optimization', 'thermal', 'insulation', } \\
\text { 'infrastructure', 'relevant', 'value', } \\
\text { 'relation', 'operational', 'ecology', } \\
\text { 'collected', 'consolidated', } \\
\text { 'consolidated', 'value', 'assessed', } \\
\text { 'used', 'benchmark', 'verify', 'realized' }\end{array}$ & $\begin{array}{l}\text { Roche, Annual Report 2012, p 112: } \\
\text { "[...] measures to reduce energy consumption are } \\
\text { implemented, whether through production installations } \\
\text { equipped with intelligent energy management systems or } \\
\text { through the energy optimization and thermal insulation of } \\
\text { infrastructures. All the relevant values in relation to operational } \\
\text { ecology are collected and consolidated annually. These } \\
\text { consolidated values are assessed and used as a benchmark to } \\
\text { verify realized objectives" }\end{array}$ \\
\hline$T_{S O C}$ & $\begin{array}{l}\mathrm{T}_{\mathrm{SOC}}: \text { 'corporate', 'social', } \\
\text { 'responsibility', 'includes', 'support', } \\
\text { 'social', 'institution', 'local', 'basis', } \\
\text { 'demonstrate', 'social', } \\
\text { 'responsibility', 'making', 'donation', } \\
\text { 'various', 'organization', 'provide', } \\
\text { 'direct', 'efficient', 'unbureaucratic' }\end{array}$ & $\begin{array}{l}\text { Wienerberger, Annual Report } 2011, p 51 \text { : } \\
\text { "This central principle of active corporate social responsibility } \\
\text { includes support for social institutions on a local basis. We do } \\
\text { not demonstrate our social responsibility by making donations } \\
\text { to various international organizations, but provide direct, } \\
\text { efficient and unbureaucratic help" }\end{array}$ \\
\hline$T_{E M P}$ & $\begin{array}{l}\mathrm{T}_{\mathrm{EMPL}} \text { : 'called', 'coaching', } \\
\text { 'performance', 'initiated', 'manager', } \\
\text { 'goal', 'strengthening', 'feedback', } \\
\text { 'culture', 'improving', 'employee', } \\
\text { 'performance', 'crucial', 'make', } \\
\text { 'high', 'performing', 'learning', } \\
\text { 'organization', 'recognized', 'best' }\end{array}$ & $\begin{array}{l}\text { Electrolux, Annual Report 2013, } \mathrm{p} 45 \text { : } \\
\text { "[...] a global training program called (Coaching for } \\
\text { Performance) was initiated in } 2013 \text { for all managers with the } \\
\text { goal of strengthening the feedback culture and improving } \\
\text { employee performance. This is crucial to make Electrolux a } \\
\text { high-performing learning organization. To be recognized as } \\
\text { the best appliance company by our employees is an important } \\
\text { vision for Electrolux" }\end{array}$ \\
\hline$T_{H R}$ & $\begin{array}{l}\mathrm{T}_{\mathrm{HR}}: \text { 'business', 'human', 'right', } \\
\text { 'ungp', 'base', 'human', 'right', } \\
\text { 'commitment', 'policy', 'bill', 'human', } \\
\text { 'right', 'universal', 'declaration', } \\
\text { 'human', 'right', 'covenant', 'civil', } \\
\text { 'political', 'right' }\end{array}$ & $\begin{array}{l}\text { Unilever, Annual Report 2013, p 17: } \\
\text { "In line with the UN Guiding Principles on Business and } \\
\text { Human Rights (UNGP), we base our human rights } \\
\text { commitment and policy on the International Bill of Human } \\
\text { Rights (the Universal Declaration of Human Rights, the } \\
\text { International Covenant on Civil and Political Rights and the } \\
\text { International Covenant on Economic, Social and Cultural } \\
\text { Rights)" }\end{array}$ \\
\hline$T_{\text {CORR }}$ & $\begin{array}{l}\mathrm{T}_{\mathrm{CORR}} \text { : 'act', 'lawful', 'manner', } \\
\text { 'particular', 'emphasis', 'placed', } \\
\text { 'compliance', 'antitrust', 'legislation', } \\
\text { 'avoidance', 'corruption', 'risk', } \\
\text { 'compliance', 'measure', } \\
\text { 'supplemented', 'range', 'internal', } \\
\text { 'policy', 'guideline', 'instruction' }\end{array}$ & $\begin{array}{l}\text { BMW Group, Annual Report 2014, } p 185 \text { : } \\
\text { A coordinated set of instruments and measures is employed to } \\
\text { ensure that the BMW Group, its representative bodies, its } \\
\text { managers and staff act in a lawful manner. Particular emphasis } \\
\text { is placed on compliance with antitrust legislation and the } \\
\text { avoidance of corruption risks. Compliance measures are } \\
\text { supplemented by a whole range of internal policies, guidelines } \\
\text { and instructions" }\end{array}$ \\
\hline$T_{B R I B}$ & $\begin{array}{l}\mathrm{T}_{\mathrm{BRIB}} \text { : 'regulation', 'relating', } \\
\text { 'import', 'export', 'control', 'money', } \\
\text { 'laundering', 'false', 'accounting', } \\
\text { 'anti', 'bribery', 'anti', 'boycott', } \\
\text { 'provision', 'non', 'compliance', } \\
\text { 'expose', 'fine', 'penalty', 'suspension' }\end{array}$ & $\begin{array}{l}\text { BAE Systems, Annual Report 2013, } p \text { 108: } \\
\text { These include, without limitation, regulations relating to import } \\
\text { export controls, money laundering, false accounting, anti- } \\
\text { bribery and anti-boycott provisions. Non-compliance could } \\
\text { expose the Group to fines, penalties, suspension or debarment, } \\
\text { which could have a material adverse effect on the Group. }\end{array}$ \\
\hline
\end{tabular}

Panel A of the table presents the top-20 word windows for each topic-specific vocabulary. The frequency of the respective word appears in the vocabulary and is indicated in parentheses. Panel B shows examples retrieved from our sample annual reports for every $T_{i}$. 
Table 3 Descriptive Statistics for all variables

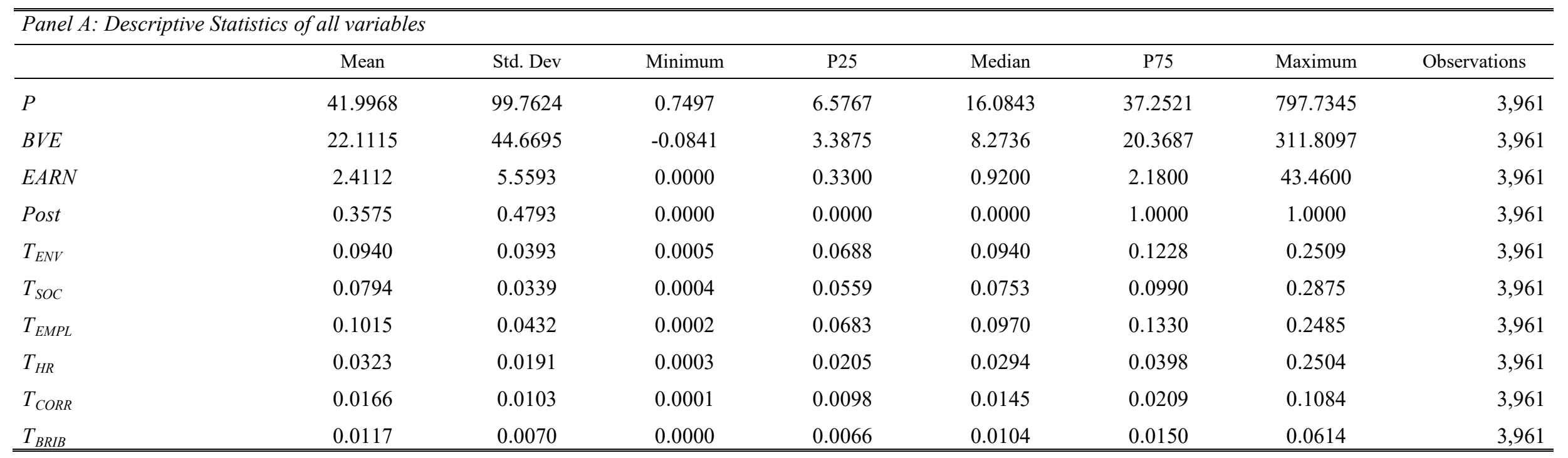

This table presents descriptive statistics for the variables used in the first stage regressions (i.e. equations (1) and (2)) 
Table 4 Correlation Matrix

\begin{tabular}{|c|c|c|c|c|c|c|c|c|c|c|}
\hline & $P$ & B BVE & EARN & Post & $\mathrm{T}_{\mathrm{ENV}}$ & $\overline{\mathrm{T}_{\mathrm{SOC}}}$ & $\overline{T_{\text {EMPL }}}$ & $\bar{~} \overline{\mathrm{T}_{\mathrm{HR}}}$ & $\mathrm{T}_{\mathrm{T}}^{\mathrm{CORR}}$ & $\overline{T_{\text {BRIB }}}$ \\
\hline$P$ & 1.0000 & & & & & & & & & \\
\hline$B V E$ & $\begin{array}{c}0.8314 \\
(0.0000)\end{array}$ & 1.0000 & & & & & & & & \\
\hline$E A R N$ & $\begin{array}{c}0.9037 \\
(0.0000)\end{array}$ & $\begin{array}{c}0.8342 \\
(0.0000)\end{array}$ & 1.0000 & & & & & & & \\
\hline Post & $\begin{array}{c}0.0735 \\
(0.0000)\end{array}$ & $\begin{array}{c}0.0270 \\
(0.0887)\end{array}$ & $\begin{array}{c}0.0321 \\
(0.0431)\end{array}$ & 1.0000 & & & & & & \\
\hline$T_{E N V}$ & $\begin{array}{l}-0.0846 \\
(0.0000)\end{array}$ & $\begin{array}{c}-0.0708 \\
(0.0000)\end{array}$ & $\begin{array}{l}-0.0571 \\
(0.0003)\end{array}$ & $\begin{array}{c}0.0762 \\
(0.0000)\end{array}$ & 1.0000 & & & & & \\
\hline$T_{S O C}$ & $\begin{array}{l}-0.0700 \\
(0.0000)\end{array}$ & $\begin{array}{c}-0.0568 \\
(0.0003)\end{array}$ & $\begin{array}{l}-0.0483 \\
(0.0024)\end{array}$ & $\begin{array}{c}0.1127 \\
(0.0000)\end{array}$ & $\begin{array}{c}0.8904 \\
(0.0000)\end{array}$ & 1.0000 & & & & \\
\hline$T_{E M P L}$ & $\begin{array}{l}-0.1070 \\
(0.0000)\end{array}$ & $\begin{array}{l}-0.1125 \\
(0.0000)\end{array}$ & $\begin{array}{l}-0.0798 \\
(0.0000)\end{array}$ & $\begin{array}{c}0.0454 \\
(0.0043)\end{array}$ & $\begin{array}{c}0.8868 \\
(0.0000)\end{array}$ & $\begin{array}{c}0.8821 \\
(0.0000)\end{array}$ & 1.0000 & & & \\
\hline$T_{H R}$ & $\begin{array}{l}-0.0485 \\
(0.0023)\end{array}$ & $\begin{array}{l}-0.0657 \\
(0.0000)\end{array}$ & $\begin{array}{l}-0.0427 \\
(0.0072)\end{array}$ & $\begin{array}{c}0.1889 \\
(0.0000)\end{array}$ & $\begin{array}{c}0.7276 \\
(0.0000)\end{array}$ & $\begin{array}{c}0.8147 \\
(0.0000)\end{array}$ & $\begin{array}{c}0.6564 \\
(0.0000)\end{array}$ & 1.0000 & & \\
\hline$T_{C O R R}$ & $\begin{array}{l}-0.0860 \\
(0.0000)\end{array}$ & $\begin{array}{l}-0.1009 \\
(0.0000)\end{array}$ & $\begin{array}{l}-0.0751 \\
(0.0000)\end{array}$ & $\begin{array}{c}0.2036 \\
(0.0000)\end{array}$ & $\begin{array}{c}0.7602 \\
(0.0000)\end{array}$ & $\begin{array}{c}0.7981 \\
(0.0000)\end{array}$ & $\begin{array}{c}0.6898 \\
(0.0000)\end{array}$ & $\begin{array}{c}0.9233 \\
(0.0000)\end{array}$ & 1.0000 & \\
\hline$T_{B R I B}$ & $\begin{array}{l}-0.1222 \\
(0.0000)\end{array}$ & $\begin{array}{l}-0.1561 \\
(0.0000)\end{array}$ & $\begin{array}{l}-0.1063 \\
(0.0000)\end{array}$ & $\begin{array}{c}0.1612 \\
(0.0000)\end{array}$ & $\begin{array}{c}0.7898 \\
(0.0000)\end{array}$ & $\begin{array}{c}0.7280 \\
(0.0000)\end{array}$ & $\begin{array}{c}0.7629 \\
(0.0000)\end{array}$ & $\begin{array}{c}0.6847 \\
(0.0000)\end{array}$ & $\begin{array}{c}0.8549 \\
(0.0000)\end{array}$ & 1.0000 \\
\hline
\end{tabular}

This table presents bivariate Pearson correlation coefficients and p-values (in parentheses) for a two-tailed test of statistical significance. 
Figure 1 Topic-Specific CSR Disclosure by Year

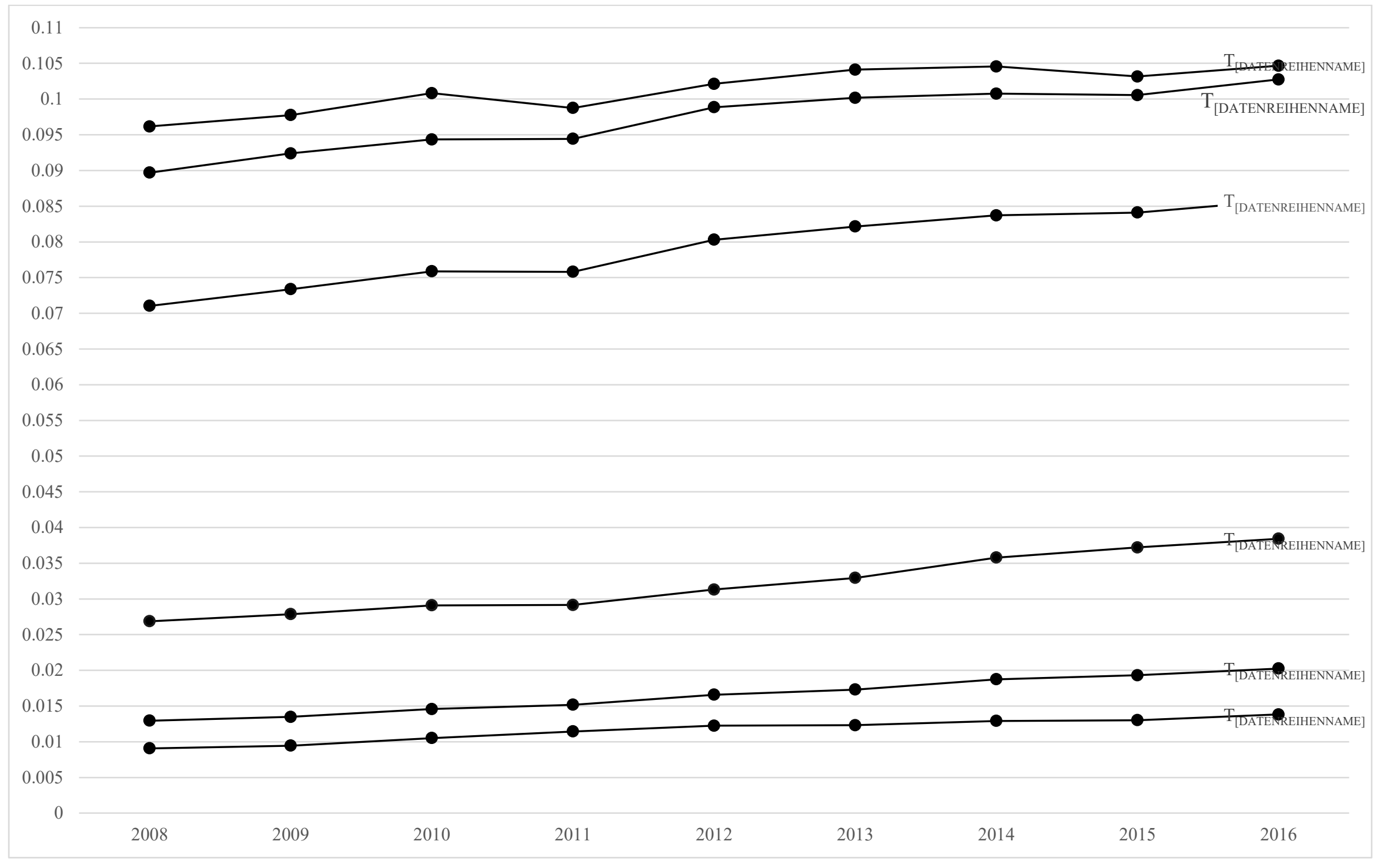


Table 5 Results for Equation (1) and (2) - Nested Price Panel Regressions Price is regressed on book value of equity and earnings, both per share and on the respective CSR disclosure measures $\mathrm{T}_{\mathrm{i}}$

\begin{tabular}{|c|c|c|c|c|c|c|c|c|}
\hline & Equation & $(1)$ & $(2)$ & $(2)$ & $(2)$ & $(2)$ & $(2)$ & $(2)$ \\
\hline \multirow[t]{2}{*}{$\overline{\mathrm{BV}}$} & & $0.9662 * * *$ & $0.9559 * * *$ & $0.9602 * * *$ & $0.9563 * * *$ & 0.9638 & $0.9576 * * *$ & $0.9483 * * *$ \\
\hline & & $(3.5071)$ & $(3.5084)$ & $(3.5078)$ & $(3.5074)$ & $(3.5114)$ & $(3.5049)$ & $(3.4985)$ \\
\hline \multirow[t]{2}{*}{ EARN } & & $2.7013 * * *$ & $2.6779 * * *$ & $2.6887 * * *$ & $2.6838 * * *$ & 2.6895 & $2.6863^{* * *}$ & $2.6706^{* * *}$ \\
\hline & & $(3.0271)$ & $(3.0487)$ & $(3.0505)$ & $(3.0535)$ & $(3.0381)$ & $(3.0490)$ & $(3.0684)$ \\
\hline $\mathrm{T}_{\mathrm{ENV}}$ & & & $\begin{array}{r}17.0286 \\
(0.7302)\end{array}$ & & & & & \\
\hline Post $^{*} \mathrm{~T}_{\mathrm{ENV}}$ & & & $\begin{array}{l}-119.7881 * * * \\
(-3.0810)\end{array}$ & & & & & \\
\hline $\mathrm{T}_{\mathrm{SOC}}$ & & & & $\begin{array}{l}47.3939^{*} \\
(1.8149)\end{array}$ & & & & \\
\hline Post $^{*} \mathrm{~T}_{\mathrm{SOC}}$ & & & & $\begin{array}{l}-104.5475^{* * *} \\
(-2.7880)\end{array}$ & & & & \\
\hline $\mathrm{T}_{\mathrm{EMPL}}$ & & & & & $\begin{array}{l}27.1312 \\
(1.3825)\end{array}$ & & & \\
\hline Post* $\mathrm{T}_{\mathrm{EMPL}}$ & & & & & $\begin{array}{l}-105.1878^{* * *} \\
(-3.4179)\end{array}$ & & & \\
\hline $\mathrm{T}_{\mathrm{HR}}$ & & & & & & $\begin{array}{l}129.566^{* *} \\
(2.1932)\end{array}$ & & \\
\hline Post $^{*} \mathrm{~T}_{\mathrm{HR}}$ & & & & & & $\begin{array}{l}-169.409 * * * \\
(-2.6723)\end{array}$ & & \\
\hline $\mathrm{T}_{\mathrm{CORR}}$ & & & & & & & $\begin{array}{c}187.2301 * \\
(1.9189)\end{array}$ & \\
\hline Post $* \mathrm{~T}_{\mathrm{CORR}}$ & & & & & & & $\begin{array}{l}-367.6679 * * * \\
(-3.1384)\end{array}$ & \\
\hline $\mathrm{T}_{\mathrm{BRIB}}$ & & & & & & & & $\begin{array}{r}78.3899 \\
(0.7799)\end{array}$ \\
\hline Post $^{*} \mathrm{~T}_{\mathrm{BRIB}}$ & & & & & & & & $\begin{array}{l}-733.3985^{* * *} \\
(-4.4339)\end{array}$ \\
\hline Constant & & 1.0608 & -0.2413 & -2.1731 & -1.3256 & -2.3523 & -1.1750 & 0.6983 \\
\hline & & $(0.2154)$ & $(-0.0433)$ & $(-0.3920)$ & $(-0.2443)$ & $(-0.4299)$ & $(-0.2260)$ & $(0.1407)$ \\
\hline Cluster & & FIRM & FIRM & FIRM & FIRM & FIRM & FIRM & FIRM \\
\hline Firm fixed effects & & YES & YES & YES & YES & YES & YES & YES \\
\hline Year fixed effects & & YES & YES & YES & YES & YES & YES & YES \\
\hline Adj. R-squared & & 0.9603 & 0.9548 & 0.9606 & 0.9607 & 0.9605 & 0.9606 & 0.9610 \\
\hline$F$ & & 18.46 & 16.97 & 17.11 & 16.70 & 17.62 & 16.67 & 17.41 \\
\hline Observations & & 3,961 & 3,961 & 3,961 & 3,961 & 3,961 & 3,961 & 3,961 \\
\hline
\end{tabular}

This table reports ordinary least squares coefficient estimates and t-statistics (in parentheses) based on the standard variance estimator. ***, **, and * indicate statistical significance at the $1 \%, 5 \%$ and $10 \%$ levels (two-tailed), respectively. This table reports the results for the effect of topic-specific CSR disclosure on prices analysed via panel with fixed effects for years and cross-section. A description of the variables under consideration can be found in table I in the appendix. 
Table 6 Descriptives of $R^{2}$ of pooled Equations (1) and (2) on firm level

\begin{tabular}{|c|c|c|c|c|c|c|c|}
\hline & $R^{2}(B)$ & $R^{2}\left(T_{E N V}\right)$ & $R^{2}\left(T_{S O C}\right)$ & $R^{2}\left(T_{E M P L}\right)$ & $R^{2}\left(T_{H R}\right)$ & $R^{2}\left(T_{C O R R}\right)$ & $R^{2}\left(T_{B R I B}\right)$ \\
\hline Mean & 0.4934 & 0.6147 & 0.6218 & 0.6182 & 0.6259 & 0.6251 & 0.6264 \\
\hline Std. Dev. & 0.3773 & 0.3616 & 0.35929 & 0.3524 & 0.3502 & 0.3556 & 0.3504 \\
\hline Median & 0.5820 & 0.7403 & 0.74398 & 0.7343 & 0.7411 & 0.7377 & 0.7456 \\
\hline Observations & 3,303 & 3,303 & 3,303 & 3,303 & 3,303 & 3,303 & 3,303 \\
\hline
\end{tabular}

This table presents the results for the incremental changes; in the first column the adjusted $\mathrm{R}^{2}$ for the pooled estimation of equation (1) is presented, whereas the remaining columns show the adjusted $\mathrm{R}^{2}$ from the effect of the respective textual disclosure on prices analysed via pooled regressions of equation (2).

Table 7 Results for Equation (3) - Incremental Value Relevance of Institutional Environment Herein we regress $\mathrm{R}^{2}{ }_{\text {inc }}\left(T_{i}\right)$ on the institutional factors, controlling for industry and country-fixed effects

\begin{tabular}{|c|c|c|c|c|c|c|}
\hline & $R_{\text {incr }}^{2}\left(T_{E N V}\right)$ & $R_{\text {incr }}^{2}\left(T_{S O C}\right)$ & $R_{\text {incr }}^{2}\left(T_{E M P L}\right)$ & $R_{\text {incr }}^{2}\left(T_{H R}\right)$ & $R_{\text {incr }}^{2}\left(T_{\text {CORR }}\right)$ & $R_{\text {incr }}^{2}\left(T_{B R I B}\right)$ \\
\hline \multirow[t]{2}{*}{$\overline{\text { factor_csr }}$} & $-0.1608^{* * *}$ & $-0.2406^{* * *}$ & $-0.2266^{* * *}$ & $-0.2164 * * *$ & $-0.1693 * * *$ & $-0.2322 * * *$ \\
\hline & $(-4.1494)$ & $(-6.2234)$ & $(-6.1269)$ & $(-5.4616)$ & $(-4.2202)$ & $(-5.8580)$ \\
\hline \multirow[t]{2}{*}{ factor_empl } & $-0.2443 * * *$ & $-0.3158 * * *$ & $-0.3255^{* *}$ & $-0.1649 * *$ & $-0.1322 *$ & $-0.1580 * *$ \\
\hline & $(-3.7194)$ & $(-4.8196)$ & $(-5.1931)$ & $(-2.4557)$ & $(-1.9439)$ & $(-2.3516)$ \\
\hline \multirow[t]{2}{*}{ factor_leg } & 0.1095 & 0.2329 & 0.0427 & $0.5100 * * *$ & $0.7075 * * *$ & $0.6979 * * *$ \\
\hline & $(0.6423)$ & $(1.3688)$ & $(0.2626)$ & $(2.9257)$ & $(4.0089)$ & $(4.0009)$ \\
\hline \multirow[t]{2}{*}{ factor_enf } & $1.1803 * * *$ & $1.4657 * * *$ & $1.6101 * * *$ & $0.6395 * *$ & 0.3067 & 0.4533 \\
\hline & $(3.7776)$ & $(4.7022)$ & $(5.4000)$ & $(2.0022)$ & $(0.9483)$ & $(1.4182)$ \\
\hline \multirow[t]{2}{*}{ Constant } & -0.1443 & $-0.2672 * *$ & -0.1554 & $-0.3403 * * *$ & $-0.5110 * * *$ & $-0.5206 * * *$ \\
\hline & $(-1.1682)$ & $(-2.1677)$ & $(-1.3181)$ & $(-2.6947)$ & $(-3.9961)$ & $(-4.1193)$ \\
\hline Industry fixed effects & YES & YES & YES & YES & YES & YES \\
\hline Country fixed effects & YES & YES & YES & YES & YES & YES \\
\hline Observations & 3,303 & 3,303 & 3,303 & 3,303 & 3,303 & 3,303 \\
\hline$R$-squared & 0.05753 & 0.0924 & 0.0979 & 0.0712 & 0.0640 & 0.0746 \\
\hline$F$ & 10.68 & 13.34 & 14.22 & 10.05 & 8.964 & 10.57 \\
\hline
\end{tabular}

This table reports ordinary least squares coefficient estimates and t-statistics (in parentheses) based on the standard variance estimator. $* * *, * *$, and $*$ indicate statistical significance at the $1 \%, 5 \%$ and $10 \%$ levels (two-tailed), respectively. The dependent variable is $\mathrm{R}_{\text {incr }}\left(\mathrm{T}_{\mathrm{i}}\right)$, the incremental value relevance attributable to the addition of the topic-specific CSR disclosure. factor_csr, factor empl, factor leg and factor enf are four factors measuring the

strength of the institutional environment with respect to CSR, employee, leg and enforcement issues. The factors are generated through a PCA with

Oblimin rotations. See table 2 for a description of the institutional variables. 
Table 8 Results for Equation (3) controlling for Financial Characteristics of the Firms We regress $R_{\text {incr }}^{2}\left(T_{i}\right)$ on the institutional factors and add financial characteristics including size, leverage and profitability, controlling for industry- and country-fixed effects.

\begin{tabular}{|c|c|c|c|c|c|c|}
\hline & $R_{\text {incr }}^{2}\left(T_{E N V}\right)$ & $R_{\text {incr }}^{2}\left(T_{S O C}\right)$ & $R_{\text {incr }}^{2}\left(T_{E M P L}\right)$ & $R_{\text {incr }}^{2}\left(T_{H R}\right)$ & $R_{\text {incr }}^{2}\left(T_{C O R R}\right)$ & $R_{\text {incr }}^{2}\left(T_{B R I B}\right)$ \\
\hline \multirow[t]{2}{*}{$\overline{\text { factor_csr }}$} & $-0.1668 * * *$ & $-0.2467 * * *$ & $-0.2343 * * *$ & $-0.2229 * * *$ & $-0.1759 * * *$ & $-0.2388 * * *$ \\
\hline & $(-4.3071)$ & $(-6.3923)$ & $(-6.3624)$ & $(-5.6343)$ & $(-4.3926)$ & $(-6.0501)$ \\
\hline \multirow[t]{2}{*}{ factor_empl } & $-0.2584 * * *$ & $-0.3357 * * *$ & $-0.3454 * * *$ & $-0.1804 * * *$ & $-0.1488 * *$ & $-0.1804 * * *$ \\
\hline & $(-3.9309)$ & $(-5.1264)$ & $(-5.5268)$ & $(-2.6858)$ & $(-2.1903)$ & $(-2.6928)$ \\
\hline \multirow[t]{2}{*}{ factor_leg } & 0.0924 & 0.2031 & 0.0186 & $0.4928 * * *$ & $0.6885^{* * *}$ & $0.6699 * * *$ \\
\hline & $(0.5412)$ & $(1.1941)$ & $(0.1145)$ & $(2.8254)$ & $(3.9006)$ & $(3.8500)$ \\
\hline \multirow[t]{2}{*}{ factor_enf } & $1.2473 * * *$ & $1.5624 * * *$ & $1.7045 * * *$ & $0.7115 * *$ & 0.3840 & $0.5574^{*}$ \\
\hline & $(3.9865)$ & $(5.0122)$ & $(5.7300)$ & $(2.2262)$ & $(1.1871)$ & $(1.7481)$ \\
\hline \multirow[t]{2}{*}{ size } & $-0.0145^{* * *}$ & $-0.0151 * * *$ & $-0.0173 * * *$ & $-0.0148 * * *$ & $-0.0147 * * *$ & $-0.0149 * * *$ \\
\hline & $(-4.2123)$ & $(-4.4269)$ & $(-5.3182)$ & $(-4.2300)$ & $(-4.1438)$ & $(-4.2711)$ \\
\hline \multirow[t]{2}{*}{ leverage } & 0.0267 & $0.0640 * * *$ & $0.0520 * *$ & 0.0336 & $0.0440 *$ & $0.0891 * * *$ \\
\hline & $(1.0901)$ & $(2.6222)$ & $(2.2336)$ & $(1.3439)$ & $(1.7382)$ & $(3.5694)$ \\
\hline \multirow[t]{2}{*}{ profitability } & $-0.1061 * * *$ & $-0.1008 * * *$ & $-0.1183^{* * *}$ & $-0.1177 * * *$ & $-0.1249 * * *$ & $-0.1254 * * *$ \\
\hline & $(-3.1691)$ & $(-3.0213)$ & $(-3.7148)$ & $(-3.4402)$ & $(-3.6085)$ & $(-3.6738)$ \\
\hline \multirow[t]{2}{*}{ Constant } & 0.0850 & -0.0329 & 0.1141 & -0.1066 & $-0.2806^{* *}$ & $-0.2961 * * *$ \\
\hline & $(0.6266)$ & $(-0.2435)$ & $(0.8848)$ & $(-0.7696)$ & $(-2.0012)$ & $(-2.1417)$ \\
\hline Industry fixed effects & YES & YES & YES & YES & YES & YES \\
\hline Country fixed effects & YES & YES & YES & YES & YES & YES \\
\hline cObservations & 3,285 & 3,285 & 3,285 & 3,285 & 3,285 & 3,285 \\
\hline$R$-squared & 0.0828 & 0.1021 & 0.1107 & 0.0794 & 0.0729 & 0.0876 \\
\hline$F$ & 10.49 & 13.22 & 14.47 & 10.04 & 9.142 & 11.16 \\
\hline
\end{tabular}

This table reports ordinary least squares coefficient estimates and t-statistics (in parentheses) based on standard variance estimator. $* * *, * *$, and $*$ indicate statistical

significance at the $1 \%, 5 \%$ and $10 \%$ levels (two-tailed), respectively. The dependent variable is $\mathrm{R}_{\text {incr }}\left(\mathrm{T}_{\mathrm{i}}\right.$ ), the incremental value relevance attributable to the addition of the topic-specific CSR disclosure. factor_csr, factor_empl, factor_leg and factor_enf are four factors measuring the strength of the institutional environment with respect to CSR, employee, leg and enforcement issues. The factors are generated through a PCA with Oblimin rotations. See table 2 for a description of the institutional variables. All other variables are shown in table I in the appendix and winsorized at the top and bottom $1 \%$. 
Table 9 Results for Equation (3) controlling CSR performance We regress $R_{\text {incr }}^{2}\left(T_{i}\right)$ on the institutional factors and CSR performance measured either by A4IR or DJSI, controlling for industry- and country-fixed effects.

\begin{tabular}{|c|c|c|c|c|c|c|c|c|c|c|c|c|}
\hline \multirow{3}{*}{$\overline{\text { factor_csr }}$} & \multicolumn{2}{|c|}{$\bar{R}_{\text {incr }}^{2}\left(T_{E N V}\right)$} & \multicolumn{2}{|c|}{$\overline{R_{\text {incr }}^{2}\left(T_{S O C}\right)}$} & \multicolumn{2}{|c|}{$R_{\text {incr }}^{2}\left(T_{E M P L}\right)$} & \multicolumn{2}{|c|}{$\overline{R_{\text {incr }}^{2}\left(T_{H R}\right)}$} & \multicolumn{2}{|c|}{$R_{\text {incr }}^{2}\left(T_{\text {CORR }}\right)$} & \multicolumn{2}{|c|}{$R_{\text {in }}^{2}\left(T_{B R I B}\right)$} \\
\hline & $-0.1762^{* * *}$ & $-0.1521^{* * *}$ & $-0.2580^{* * *}$ & $-0.2317^{* * *}$ & $-0.2480^{* * * *}$ & $-0.2197^{* * *}$ & $-0.2320^{* * *}$ & $-0.2086^{* * *}$ & $-0.1904^{* * *}$ & $-0.1612^{* * *}$ & $-0.2542^{* * *}$ & $-0.2231^{* * *}$ \\
\hline & $(-4.3573)$ & $(-3.9338)$ & $(-6.3892)$ & $(-6.0035)$ & $(-6.4358)$ & $(-5.9424)$ & $(-5.6001)$ & $(-5.2734)$ & $(-4.5450)$ & $(-4.0248)$ & $(-6.1448)$ & $(-5.6422)$ \\
\hline \multirow[t]{2}{*}{ factor_empl } & $-0.2957^{* * *}$ & $-0.2228^{* * *}$ & $-0.3640^{* * *}$ & $-0.2930^{* * *}$ & $-0.3795^{* * *}$ & $-0.3081^{* * *}$ & $-0.2122^{* * *}$ & $-0.1457^{* *}$ & $-0.1889^{* * *}$ & $-0.1123^{*}$ & $-0.2190^{* * *}$ & $-0.1356^{* *}$ \\
\hline & $(-4.3868)$ & $(-3.3908)$ & $(-5.4072)$ & $(-4.4683)$ & $(-5.9077)$ & $(-4.9039)$ & $(-3.0716)$ & $(-2.1677)$ & $(-2.7049)$ & $(-1.6502)$ & $(-3.1751)$ & $(-2.0177)$ \\
\hline \multirow[t]{2}{*}{ factor_leg } & 0.0293 & 0.1262 & 0.1806 & 0.2511 & -0.0010 & 0.0567 & $0.444^{* *}$ & $0.5247^{* * *}$ & $0.6520^{* * *}$ & $0.7227^{* * *}$ & $0.6351^{* * *}$ & $0.7152^{* * *}$ \\
\hline & $(0.1671)$ & $(0.7422)$ & $(1.0326)$ & $(1.4804)$ & $(-0.0061)$ & $(0.3487)$ & $(2.4736)$ & $(3.0167)$ & $(3.5927)$ & (4.1044) & $(3.5434)$ & $(4.1131)$ \\
\hline \multirow[t]{2}{*}{ factor_enf } & $1.4145^{* * *}$ & $1.0837^{* * *}$ & $1.6739^{* * *}$ & $1.3630^{* * *}$ & $1.8385^{* * *}$ & $1.5317^{* * *}$ & $0.8500^{* * *}$ & $0.5535^{*}$ & $0.5503^{*}$ & 0.2176 & $0.7168^{* *}$ & 0.3527 \\
\hline & $(4.4774)$ & $(3.4683)$ & $(5.3053)$ & $(4.3712)$ & $(6.1061)$ & $(5.1268)$ & $(2.6254)$ & $(1.7315)$ & $(1.6811)$ & $(0.6726)$ & $(2.2171)$ & $(1.1035)$ \\
\hline \multirow[t]{2}{*}{ a4ir } & 0.0000 & & 0.0003 & & 0.0001 & & 0.0002 & & 0.0004 & & 0.0003 & \\
\hline & $(0.1168)$ & & (1.1810) & & $(0.2983)$ & & $(0.9517)$ & & (1.4197) & & (1.3942) & \\
\hline \multirow[t]{2}{*}{ djsi } & & $0.0409^{* * *}$ & & $0.0436^{* * *}$ & & $0.0335^{* * *}$ & & $0.0361^{* * *}$ & & $0.0376^{* * *}$ & & $0.0427^{* * *}$ \\
\hline & & $(3.6354)$ & & $(3.8767)$ & & (3.1113) & & $(3.1345)$ & & (3.2203) & & (3.7047) \\
\hline \multirow[t]{2}{*}{ Constant } & -0.1273 & -0.1498 & $-0.2891^{* *}$ & $-0.2733^{* *}$ & -0.1721 & -0.1602 & $-0.3459^{* * *}$ & $-0.3449^{* * *}$ & $-0.5456^{* * *}$ & $-0.5158^{* * *}$ & $-0.5529^{* * *}$ & $-0.5263^{* * *}$ \\
\hline & $(-0.9813)$ & $(-1.2166)$ & $(-2.2318)$ & $(-2.2241)$ & $(-1.3921)$ & $(-1.3609)$ & $(-2.6027)$ & $(-2.7381)$ & $(-4.0598)$ & $(-4.0449)$ & $(-4.1658)$ & $(-4.1791)$ \\
\hline Industry fixed effects & YES & YES & YES & YES & YES & YES & YES & YES & YES & YES & YES & YES \\
\hline Country fixed effects & YES & YES & YES & YES & YES & YES & YES & YES & YES & YES & YES & YES \\
\hline Observations & 3,165 & 3,297 & 3,165 & 3,297 & 3,165 & 3,297 & 3,165 & 3,297 & 3,165 & 3,297 & 3,165 & 3,297 \\
\hline$R$-squared & 0.0808 & 0.0796 & 0.0957 & 0.0969 & 0.1044 & 0.1006 & 0.0724 & 0.0741 & 0.0652 & 0.0671 & 0.0776 & 0.0788 \\
\hline$F$ & 10.61 & 10.88 & 12.77 & 13.50 & 14.07 & 14.07 & 9.421 & 10.07 & 8.418 & 9.040 & 10.15 & 10.75 \\
\hline
\end{tabular}

This table reports ordinary least squares coefficient estimates and t-statistics (in parentheses) based on the standard variance estimator. ***, **, and * indicate statistical significance at the $1 \%, 5 \%$ and $10 \%$ levels (two-tailed), respectively. The dependent variable is $\mathrm{R}_{\text {incr }}\left(\mathrm{T}_{\mathrm{i}}\right)$, the incremental value relevance attributable to the addition of the topic-specific CSR disclosure. factor_csr, factor_empl, factor_leg and factor_enf are four factors measuring the strength of the institutional environment with respect to CSR, employee, leg and enforcement issues. The factors are generated through a PCA with Oblimin rotations. See table 2 for a description of the institutional variables. All other variables are shown in table I in the appendix and winsorized at the top and bottom $1 \%$. 
Table 10 Results for Equation (3) controlling for Textual Characteristics We regress $R_{\text {incr }}^{2}\left(T_{i}\right)$ on the Institutional Environment and Textual Characteristics of the Annual Report, namely readability and tone, controlling for industry- and country-fixed effects.

\begin{tabular}{|c|c|c|c|c|c|c|}
\hline & $R_{\text {incr }}^{2}\left(T_{E N V}\right)$ & $R_{\text {incr }}^{2}\left(T_{S O C}\right)$ & $R_{\text {incr }}^{2}\left(T_{E M P L}\right)$ & $R_{\text {incr }}^{2}\left(T_{H R}\right)$ & $R_{\text {incr }}^{2}\left(T_{\text {CORR }}\right)$ & $R_{\text {incr }}^{2}\left(T_{B R I B}\right)$ \\
\hline \multirow[t]{2}{*}{ factor_csr } & $-0.1615 * * *$ & $-0.2413 * * *$ & $-0.2271 * * *$ & $-0.2171 * * *$ & $-0.1700 * * *$ & $-0.2329 * * *$ \\
\hline & $(-4.1775)$ & $(-6.2634)$ & $(-6.1548)$ & $(-5.4956)$ & $(-4.2525)$ & $(-5.8916)$ \\
\hline \multirow[t]{2}{*}{ factor_empl } & $-0.2442 * * *$ & $-0.3148 * * *$ & $-0.3335^{* * *}$ & $-0.1671 * *$ & $-0.1310 *$ & $-0.1566^{* *}$ \\
\hline & $(-3.6985)$ & $(-4.7817)$ & $(-5.2887)$ & $(-2.4766)$ & $(-1.9174)$ & $(-2.3189)$ \\
\hline \multirow[t]{2}{*}{ factor_leg } & 0.1375 & 0.2656 & 0.0525 & $0.5360 * * *$ & $0.7411 * * *$ & $0.7293 * * *$ \\
\hline & $(0.8053)$ & $(1.5600)$ & $(0.3220)$ & $(3.0712)$ & $(4.1952)$ & $(4.1748)$ \\
\hline \multirow[t]{2}{*}{ factor_enf } & $1.1474 * * *$ & $1.4247 * * *$ & $1.6200 * * *$ & $0.6152 *$ & 0.2643 & 0.4129 \\
\hline & $(3.6526)$ & $(4.5495)$ & $(5.4012)$ & $(1.9162)$ & $(0.8135)$ & $(1.2852)$ \\
\hline \multirow[t]{2}{*}{ discl_tone } & $-2.0290 * * *$ & $-2.2841 * * *$ & $-1.4547 * * *$ & $-2.1027 * * *$ & $-2.3322 * * *$ & $-2.1535 * * *$ \\
\hline & $(-3.8329)$ & $(-4.3281)$ & $(-2.8780)$ & $(-3.8867)$ & $(-4.2590)$ & $(-3.9773)$ \\
\hline \multirow[t]{2}{*}{ discl_readability } & 0.0297 & 0.0309 & $0.0426^{* *}$ & $0.0370^{*}$ & 0.0312 & 0.0281 \\
\hline & $(1.5244)$ & $(1.5921)$ & $(2.2897)$ & $(1.8569)$ & $(1.5502)$ & $(1.4087)$ \\
\hline \multirow[t]{2}{*}{ Constant } & -0.1404 & $-0.2640 * *$ & -0.1418 & $-0.3331 * * *$ & $-0.5079 * * *$ & $-0.5182 * * *$ \\
\hline & $(-1.1351)$ & $(-2.1413)$ & $(-1.2010)$ & $(-2.6355)$ & $(-3.9702)$ & $(-4.0960)$ \\
\hline Industry fixed effects & YES & YES & YES & YES & YES & YES \\
\hline Country fixed effects & YES & YES & YES & YES & YES & YES \\
\hline Observations & 3,303 & 3,303 & 3,303 & 3,303 & 3,303 & 3,303 \\
\hline$R$-squared & 0.0808 & 0.0990 & 0.1023 & 0.0773 & 0.0706 & 0.0803 \\
\hline$F$ & 10.66 & 13.33 & 13.82 & 10.16 & 9.218 & 10.59 \\
\hline
\end{tabular}

This table reports ordinary least squares coefficient estimates and t-statistics (in parentheses) based on standard variance estimator. ***, **, and * indicate statistical significance at the $1 \%, 5 \%$ and $10 \%$ levels (two-tailed), respectively. The dependent variable is $\mathrm{R}_{\text {incr }}\left(\mathrm{T}_{\mathrm{i}}\right)$, the incremental value relevance attributable to the addition of the topic-specific CSR disclosure. factor_csr, factor empl, factor leg and factor enf are four factors measuring the strength of the institutional environment with respect to CSR, employee, leg and enforcement issues. The factors are generated through a PCA with Oblimin rotations. See table 2 for a description of the institutional variables. All other variables are shown in table I in the appendix and winsorized at the top and bottom $1 \%$. 
Table 11 Results for Equation (3) - Incremental Value Relevance of Institutional Environment based on aggregated four factors We regress $R_{i n c r}^{2}\left(T_{i}\right)$ on the factor_inst, controlling for industry and country-fixed effects

\begin{tabular}{|c|c|c|c|c|c|c|}
\hline & $R_{\text {incr }}^{2}\left(T_{E N V}\right)$ & $R_{\text {incr }}^{2}\left(T_{S O C}\right)$ & $R_{\text {incr }}^{2}\left(T_{E M P L}\right)$ & $R_{\text {incr }}^{2}\left(T_{H R}\right)$ & $R_{\text {incr }}^{2}\left(T_{C O R R}\right)$ & $R_{\text {incr }}^{2}\left(T_{B R I B}\right)$ \\
\hline \multirow{2}{*}{$\overline{\text { factor_inst }}$} & -0.0559 & $-0.1065 * * *$ & $-0.0903 * *$ & $-0.0941 * *$ & $-0.1064 * * *$ & $-0.1417 * * *$ \\
\hline & $(-1.4849)$ & $(-2.8373)$ & $(-2.5139)$ & $(-2.4456)$ & $(-2.7308)$ & $(-3.6796)$ \\
\hline \multirow[t]{2}{*}{ Constant } & $0.0596 * * *$ & $0.0521 * *$ & 0.0357 & $0.0751 * * *$ & $0.0484 * *$ & 0.0260 \\
\hline & $(2.5143)$ & $(2.2048)$ & $(1.5796)$ & $(3.0975)$ & $(1.9716)$ & $(1.0714)$ \\
\hline Industry fixed effects & YES & YES & YES & YES & YES & YES \\
\hline Country fixed effects & YES & YES & YES & YES & YES & YES \\
\hline Observations & 3,303 & 3,303 & 3,303 & 3,303 & 3,303 & 3,303 \\
\hline$R$-squared & 0.0753 & 0.0924 & 0.0979 & 0.0712 & 0.0640 & 0.0746 \\
\hline$F$ & 10.68 & 13.34 & 14.22 & 10.05 & 8.964 & 10.57 \\
\hline
\end{tabular}

This table reports ordinary least squares coefficient estimates and t-statistics (in parentheses) based on the standard variance estimator. $* * *, * *$, and $*$ indicate statistical significance at the $1 \%, 5 \%$ and $10 \%$ levels (two-tailed), respectively. The dependent variable is $\mathrm{R}_{\text {incr }}\left(\mathrm{T}_{\mathrm{i}}\right)$, the incremental value relevance attributable to the addition of the topic-specific CSR disclosure. factor_inst is our composite measure of the strength of the institutional environment that is equal to the mean of the four factors generated through a PCA. See table 2 for a description of the institutional variables. 
Table 12 Results for Equation (3) - Incremental Value Relevance of the Institutional Environment differentiating between good and bad CSR performers

We regress $R_{\text {incr }}^{2}\left(T_{i}\right)$ on the factor_inst and an interaction between factor_inst and good CSR performers measured either by an inclusion in the DJSI or an above median A4IR performance, controlling for industry and country-fixed effects

\begin{tabular}{|c|c|c|c|c|c|c|c|c|c|c|c|c|}
\hline \multirow{3}{*}{$\overline{\text { factor_inst }}$} & \multicolumn{2}{|c|}{$R_{\text {incr }}^{2}\left(T_{E N V}\right)$} & \multicolumn{2}{|c|}{$R_{\text {incr }}^{2}\left(T_{S O C}\right)$} & \multicolumn{2}{|c|}{$R_{\text {incr }}^{2}\left(T_{E M P L}\right)$} & \multicolumn{2}{|c|}{$R_{\text {incr }}^{2}\left(T_{H R}\right)$} & \multicolumn{2}{|c|}{$R_{\text {incr }}^{2}\left(T_{\text {CORR }}\right)$} & \multicolumn{2}{|c|}{$R_{\text {incr }}^{2}\left(T_{B R I B}\right)$} \\
\hline & -0.0368 & -0.0542 & $-0.0837^{* *}$ & $-0.1065^{* * *}$ & $-0.0723^{* *}$ & $-0.0861^{* *}$ & $-0.0744^{*}$ & $-0.0855^{* *}$ & $-0.0895^{* *}$ & $-0.1038^{* * *}$ & $-0.1235^{* * *}$ & $-0.1395^{* * *}$ \\
\hline & $(-0.9763)$ & $(-1.4152)$ & $(-2.2305)$ & $(-2.7868)$ & $(-2.0088)$ & $(-2.3550)$ & $(-1.9331)$ & $(-2.1844)$ & $(-2.2941)$ & $(-2.6161)$ & $(-3.2067)$ & $(-3.5595)$ \\
\hline \multirow[t]{2}{*}{ DJSI $=1$} & $0.0549^{* * *}$ & & $0.0634^{* * *}$ & & $0.0496^{* * *}$ & & $0.0533^{* * *}$ & & $0.0490^{* * *}$ & & $0.0540^{* * *}$ & \\
\hline & $(4.5292)$ & & $(5.2425)$ & & $(4.2808)$ & & $(4.2966)$ & & $(3.8956)$ & & $(4.3477)$ & \\
\hline \multirow[t]{2}{*}{ DJSI*factor_inst } & $-0.0611^{* * *}$ & & $-0.0863^{* * *}$ & & $-0.0703^{* * *}$ & & $-0.0749^{* * *}$ & & $-0.0498^{* *}$ & & $-0.0493^{* *}$ & \\
\hline & $(-3.0805)$ & & $(-4.3715)$ & & $(-3.7108)$ & & $(-3.6954)$ & & $(-2.4223)$ & & $(-2.4293)$ & \\
\hline \multirow[t]{2}{*}{ a4ir_good } & & -0.0060 & & -0.0109 & & -0.0089 & & -0.0004 & & -0.0058 & & -0.0069 \\
\hline & & $(-0.5741)$ & & $(-1.0399)$ & & $(-0.8897)$ & & $(-0.0369)$ & & $(-0.5352)$ & & $(-0.6410)$ \\
\hline \multirow[t]{2}{*}{ a4ir_good*factor } & & -0.0067 & & -0.0043 & & -0.0145 & & -0.0226 & & -0.0092 & & -0.0083 \\
\hline & & $(-0.4020)$ & & $(-0.2580)$ & & $(-0.9114)$ & & $(-1.3251)$ & & $(-0.5309)$ & & $(-0.4887)$ \\
\hline \multirow[t]{2}{*}{ Constant } & $0.0431^{*}$ & $0.0617^{* *}$ & 0.0314 & $0.0566^{* *}$ & 0.0191 & $0.0385^{*}$ & $0.0574^{* *}$ & $0.0733^{* * *}$ & 0.0342 & $0.0502^{* *}$ & 0.0110 & 0.0283 \\
\hline & (1.8069) & $(2.5368)$ & $(1.3218)$ & $(2.3337)$ & $(0.8390)$ & $(1.6570)$ & $(2.3545)$ & $(2.9477)$ & $(1.3850)$ & $(1.9929)$ & $(0.4492)$ & $(1.1385)$ \\
\hline Industry fixed effects & YES & YES & YES & YES & YES & YES & YES & YES & YES & YES & YES & YES \\
\hline Country fixed effects & YES & YES & YES & YES & YES & YES & YES & YES & YES & YES & YES & YES \\
\hline Observations & 3,297 & 3,303 & 3,297 & 3,303 & 3,297 & 3,303 & 3,297 & 3,303 & 3,297 & 3,303 & 3,297 & 3,303 \\
\hline$R$-squared & 0.0823 & 0.0755 & 0.1022 & 0.0929 & 0.1044 & 0.0987 & 0.0780 & 0.0719 & 0.0687 & 0.0643 & 0.0804 & 0.0749 \\
\hline$F$ & 10.85 & 9.912 & 13.78 & 12.42 & 14.11 & 13.28 & 10.24 & 9.391 & 8.935 & 8.334 & 10.59 & 9.822 \\
\hline
\end{tabular}

This table reports ordinary least squares coefficient estimates and t-statistics (in parentheses) based on the standard variance estimator. $* * *, * *$, and $*$ indicate statistical significance at the $1 \%, 5 \%$ and $10 \%$ levels (two-tailed), respectively. The dependent variable is $\mathrm{R}_{\text {incr }}\left(\mathrm{T}_{\mathrm{i}}\right.$ ), the incremental value relevance attributable to the addition of the topic-specific CSR disclosure. factor_inst is our composite measure of the strength of the institutional environment that is equal to the mean of the four factors generated through a PCA. A4IR_good is 1 if the company has an above median score and zero otherwise. See table 2 for a description of the institutional variables. 